\title{
Novel Roles for Osteopontin and Clusterin in Peripheral Motor and Sensory Axon Regeneration
}

\author{
Megan C. Wright, ${ }^{1}$ Ruifa Mi, ${ }^{1}$ Emmalynn Connor, ${ }^{1}$ Nicole Reed, ${ }^{1}$ Alka Vyas, ${ }^{3}$ Manula Alspalter, ${ }^{3}$ Giovanni Coppola, ${ }^{4}$ \\ Daniel H. Geschwind, ${ }^{4}$ Thomas M. Brushart, ${ }^{1,3}$ and Ahmet Höke ${ }^{1,2}$ \\ Departments of ${ }^{1}$ Neurology, ${ }^{2}$ Neuroscience, and ${ }^{3}$ Orthopedics, The Johns Hopkins School of Medicine, Baltimore, Maryland 21287, and ${ }^{4}$ Departments of \\ Neurology and Psychiatry, University of California, Los Angeles, Los Angeles, California 90095
}

Previous studies demonstrated that Schwann cells (SCs) express distinct motor and sensory phenotypes, which impact the ability of these pathways to selectively support regenerating neurons. In the present study, unbiased microarray analysis was used to examine differential gene expression in denervated motor and sensory pathways in rats. Several genes that were significantly upregulated in either denervated sensory or motor pathways were identified and two secreted factors were selected for further analysis: osteopontin (OPN) and clusterin (CLU) which were upregulated in denervated motor and sensory pathways, respectively. Sciatic nerve transection induced upregulation of OPN and CLU and expression of both returned to baseline levels with ensuing regeneration. In vitro analysis using exogenously applied OPN induced outgrowth of motor but not sensory neurons. CLU, however, induced outgrowth of sensory neurons, but not motor neurons. To assess the functional importance of OPN and CLU, peripheral nerve regeneration was examined in OPN and $\mathrm{CLU}^{-I-}$ mice. When compared with $\mathrm{OPN}^{+/+}$mice, motor neuron regeneration was reduced in $0 \mathrm{PN}^{-1-}$ mice. Impaired regeneration through $\mathrm{OPN}{ }^{-I-}$ peripheral nerves grafted into $\mathrm{OPN}^{+/+}$mice indicated that loss of OPN in SCs was responsible for reduced motor regeneration. Sensory neuron regeneration was impaired in $\mathrm{CLU}^{-1-}$ mice following sciatic nerve crush and impaired regeneration nerve fibers through $\mathrm{CLU}^{-/-}$nerve grafts transplanted into $\mathrm{CLU}^{+/+}$mice indicated that reduced sensory regeneration is likely due to SCderived CLU. Together, these studies suggest unique roles for SC-derived OPN and CLU in regeneration of peripheral motor and sensory axons.

\section{Introduction}

Traditionally, Schwann cells (SCs) were categorized as expressing either a myelinating or nonmyelinating phenotype (Jessen and Mirsky, 2002). However, more recent studies that examined differences in growth factor expression between denervated sensory and motor pathways showed that SCs also express distinct sensory and motor phenotypes that influence their ability to selectively promote sensory or motor axon regeneration (Höke et al., 2006; Brushart et al., 2013). Understanding the implications of this SC heterogeneity on nerve regeneration is important if we are to improve functional outcomes of peripheral nerve injury.

Numerous studies have demonstrated that, if given equal access to both denervated motor and sensory pathways, regenerating motor axons preferentially regenerate through motor pathways toward target muscle, a process that is termed "preferential motor reinnervation" (PMR; Brushart, 1988). The molec-

Received Sept. 6, 2013; revised Dec. 13, 2013; accepted Dec. 18, 2013.

Author contributions: M.C.W., R.M., G.C., D.H.G., T.M.B., and A.H. designed research; M.C.W., R.M., E.C., N.R., A.V., M.A., G.C., D.H.G., and A.H. performed research; M.C.W., R.M., G.C., D.H.G., T.M.B., and A.H. analyzed data; M.C.W., G.C., D.H.G., T.M.B., and A.H. wrote the paper.

This work was supported by the Dr Miriam and Sheldon G. Adelson Medical Research Foundation and NIH Grant R01 NS034484. We thank Fuying Gao for assistance with data analysis.

Correspondence should be addressed to either of the following: Dr Ahmet Höke, Departments of Neurology and Neuroscience, 855 North Wolfe Street, Rangos Building, Room 235, Baltimore, MD 21205, E-mail: ahoke@jhmi.edu; or Dr Megan Wright, Arcadia University, 450 South Easton Road, Glenside, PA 19038, E-mail:wrightm@arcadia.edu. DOI:10.1523/JNEUROSCI.3822-13.2014

Copyright $\odot 2014$ the authors $\quad 0270-6474 / 14 / 341689-12 \$ 15.00 / 0$ ular basis for PMR has yet to be identified. Two lines of evidence, however, indicate that conditions within the denervated SC endoneurial tubes are critical for regeneration specificity. First, PMR is impaired when motor axons are forced to reinnervate muscle through incorrect sensory pathways (Brushart et al., 1998). Second, PMR is observed even when access to target end organs is denied (Brushart, 1993). These findings strongly suggest that SC tubes maintain a specific identity that is recognized by regenerating axons and that influences their regenerative behavior.

Recent experiments that examined differences in pathwayspecific growth factor expression have shown that SCs in denervated sensory and motor pathways differ significantly in their expression of several growth factors (Höke et al., 2006; Jesuraj et al., 2012; Brushart et al., 2013). Nerve growth factor, brain derived neurotrophic factor, insulin-like growth factor-1, and vascular endothelial growth factor were expressed predominately in denervated sensory pathways, and glial cell line derived neurotrophic factor (GDNF) and pleiotrophin (PTN) were expressed predominately in denervated motor pathways. Additionally, sensory and motor pathways supported regeneration on a modality-specific basis; denervated sensory pathways preferentially supported regenerating sensory axons, and denervated motor pathways selectively supported regenerating motor axons (Höke et al., 2006). These findings further support the hypothesis that denervated sensory and motor pathways regulate selective targeting of regenerating axons. 
Whereas the above experiments evaluated expression of a small number of specific growth factors, the current experiments used microarray analysis to more broadly explore differential gene expression between denervated dorsal root (sensory pathway) and ventral root (motor pathway). A number of differentially expressed genes were identified from the microarray analysis and confirmed using RT-PCR. From a list of candidate genes, two secreted factors were selected for further study. Osteopontin (OPN) was selectively upregulated in denervated motor pathways and clusterin (CLU) was selectively upregulated in denervated sensory pathways. Using a combination of in vitro axonal outgrowth and in vivo regeneration studies, we further demonstrate a critical role for OPN and CLU in peripheral motor and sensory nerve regeneration, respectively.

\section{Materials and Methods}

Animals. All surgical procedures were conducted under sterile conditions with the approval of the Johns Hopkins University Animal Care and Use Committee. Female Sprague-Dawley rats with initial weights of 100-150 $\mathrm{g}$ were used for most experiments. ChAT-eGFP transgenic, OPN and $\mathrm{CLU}^{+/+}$and ${ }^{-1-}$ mice were obtained from Jackson Mouse repository and the generation, maintenance and genotyping of thee strains have been reported previously (Liaw et al., 1998; McLaughlin et al., 2000; Tallini et al., 2006).

\section{Surgical preparations}

Dorsal and ventral root denervation. Female rats weighing between 150 and $200 \mathrm{~g}$ were anesthetized by intramuscular injection of ketamine $(87$ $\mathrm{mg} / \mathrm{kg})$ and xylazine $(13 \mathrm{mg} / \mathrm{kg})$. Dorsal roots were denervated $(n=12)$ by exposing and excising the L3, L4, and L5 dorsal root ganglia (DRGs). In a separate group of rats, the L3, L4, and L5 ventral roots were denervated by tying them off with 11-0 suture and transecting them at the L2 spinal level $(n=15)$. Fourteen days following transection, denervated dorsal and ventral roots were harvested for microarray analysis $(n=6)$ or RT-PCR analysis $(n=6)$. The contralateral, uninjured dorsal, or ventral roots were used for controls.

Sciatic nerve transection and crush. The right sciatic nerve was exposed and transected ( $n=54 ; 6$ per group) or crushed $(n=12)$ using Micro aneurysm clips (Roboz Surgical Instruments) at the upper thigh in anesthetized adult rats. The distal segments of the crushed sciatic nerves were harvested $7 \mathrm{~d}$ and 1 month postcrush and the distal segment of the transected nerves were harvested $0,1,3,7,14 \mathrm{~d}, 1,3$, and 6 months following transection for RT-PCR and Western blot analysis.

Microarray analysis. Total RNA was extracted from control and denervated dorsal and ventral roots. Four replicates were run per sample category for a total of 16 arrays. RNA quantity was assessed with Nanodrop (Nanodrop Technologies) and quality with the Agilent Bioanalyzer (Agilent Technologies). As per the manufacturer's protocol, $200 \mathrm{ng}$ of total RNA were amplified, biotinylated and hybridized to Illumina Rat Expression Beadchips, querying the expression of $\sim 22,000$ RefSeq transcripts. Raw data were analyzed by using Bioconductor packages as previously described (Coppola, 2011). Quality assessment was performed by examining the interarray Pearson correlation and clustering based on the top variant genes was assessed. Contrast analysis of differential expression was performed by using the LIMMA package (Smyth, 2004). After linear model fitting, a Bayesian estimate of differential expression was calculated, and the false discovery rate was set at $5 \%$.

RNA isolation PCR experiments. Total RNA was extracted from nerves using Trizol reagent (Invitrogen). The cDNA was synthesized using $2 \mu \mathrm{g}$ of total RNA in the presence of Ready-to-Go You-Prime First-Strand Beads (GE Healthcare) and random primers (Invitrogen). Measurements of RNA levels were performed by real-time RT-PCR using SybrGreen. The relative amount of the gene of interest was normalized to the mRNA amount of glyceraldehydes-3-phosphate dehydrogenase. To avoid the possibility of amplifying contaminating DNA, all primers were designed with an intron sequence inside the cDNA clone to be amplified. A uniform amplification of the gene product was checked by examining the melting curves of the amplified products. All reactions were per- formed with negative control samples containing no cDNA template. For all reactions, the melting temperature was $58^{\circ} \mathrm{C}$ and gel electrophoresis was performed to confirm correct amplified product size and the absence of nonspecific bands.

Protein isolation and Western blotting for OPN and CLU. Harvested nerves were collected and stored at $-80 \mathrm{C}$. Tissues were homogenized using a tissue homogenizer in ice-cold lysis buffer (T-Per reagent, Thermo Scientific), samples were centrifuged at $10,000 \times g$ for $15 \mathrm{~min}$ and supernatant stored at $-80^{\circ} \mathrm{C}$. Protein concentrations were determined by the Pierce BCA Protein Assay Kit. Equal amounts of sample (20 $\mu \mathrm{g}$ ) were loaded into lanes of a SDS polyacrylamide gel 4-15\%(Biorad), electrotransferred onto nitrocellulose membrane, and then probed with either anti-OPN [MPIIIB10(1), DSHB] or anti-CLU antibodies (antiCLU, Millipore). Immunoreactive bands were then visualized using enhanced chemiluminescence according to the manufacturer's protocol (GE Healthcare). The blots were then striped and reprobed for actin.

\section{Cell culture}

Organotypic spinal cord cultures. Organotypic spinal cord cultures were prepared from lumbar spinal cords of P3-P4 mice expressing a yellow variant of green fluorescent protein in sensory and motor neurons and their axons using a modification of the technique described previously(Vyas et al., 2010). Briefly, lumbar spinal cords were cut into $350 \mu \mathrm{m}$ transverse sections with a McIllwain tissue chopper. Six to 10 usable slices of the lumbar enlargement from an individual pup were cultured on Transwell collagen-coated membrane inserts (Corning). The inserts were placed in a 6-well culture plate containing $1 \mathrm{ml}$ of culture medium consisting of $50 \%$ minimal essential medium (Invitrogen), 25\% HBSS, 25\% heat-inactivatedhorse serum (Hyclone), $25 \mathrm{~mm}$ HEPES, $35 \mathrm{~mm}$ D-glucose, 2 mmglutamine and penicillin/streptomycin. Slices were incubated at $37^{\circ} \mathrm{C}$ in a humidified atmosphere containing $5 \% \mathrm{CO}_{2}$, and culture medium was changed every other day for 1 week. For neurite growth promoting assays, OPN $(1 \mu / \mathrm{ml})$ was added on day 1 of the culture and fresh OPN was added each time the media was changed. Experiments were performed in triplicate and repeated twice.

Murine motor neuron-neuroblastoma cell line cultures. Murine motor neuron-neuroblastoma cell line (MN1) was kindly provided by Dr Nicholas Maragakis (The Johns Hopkins University, Baltimore, MD). The cells were grown in plastic tissue culture flasks in complete growth media according to published protocols (Salazar-Grueso et al., 1991). At 80\% confluency, the cells were transferred into 24-well dishes on coverslips and induced to differentiate in the presence of sodium butyrate (1 mM) and aphidicholin $(0.4 \mathrm{mg} / \mathrm{ml}$; both from Sigma-Aldrich) with regular media. Cells were fed daily with the same media for $2 \mathrm{~d}$ before treatment with OPN or CLU. After $24 \mathrm{~h}$, cultures were fixed with $4 \%$ paraformaldehyde and stained with $\beta$-III tubulin (anti- $\beta$-III tubulin; Promega). Length of axons in each motor neuron was measured by using unbiased stereological sampling methods. Each condition was done in triplicate for both sets of experiments and repeated twice.

DRG cell culture. Disassociated primary DRG cultures were prepared as previously described (Höke et al., 2002). Briefly, DRGs from Day 15 embryos were dissected and disassociated with $0.25 \%$ trypsin in L- 15 medium. Disassociated cells were plated onto glass coverslips coated with collagen at a density of 5000 cells/well in a 24 -well culture dish. The cultures were maintained in Neurobasal medium containing $1 \%$ fetal bovine serum. OPN and CLU were added to the cultures and $24 \mathrm{~h}$ later, cells were fixed with $4 \%$ paraformaldehyde and immunostained with anti- $\beta$ III tubulin antibody. The length of the longest axon was measured by using unbiased stereological sampling methods. Each experiment was performed in triplicate and repeated twice.

Disassociated motor neuron cell culture. Embryonic rat motor neurons were enriched and cultured on poly-L-lysine- and collagen-coated coverslips as previously described (Mi et al., 2007). Briefly, motor neuronrich cell fractions were prepared by density gradient centrifugation of enzymatically dissociated ventral horns of the lumbar spinal cords of rat embryos (embryonic day 14-15) and seeded at 10,000 cells per well in a 24 -well dish. These cultures provide a near-pure neuronal population with $15-20 \%$ motor neurons. The day after plating, motor neuronenriched cell cultures were exposed to media containing OPN or CLU. 
After $24 \mathrm{~h}$, cultures were fixed with $4 \%$ paraformaldehyde and stained with anti-neurofilament antibody (SMI-312, Covance). In the mixed neuronal population, motor neurons were identified by their size and morphology (single dominant axon), and the length of axons in each motor neuron was measured by using unbiased stereological sampling methods.

Myelinating axon counts. Four weeks following nerve crush, a $1 \mathrm{~mm}$ segment of nerve that was $5 \mathrm{~mm}$ distal to the crush site was harvested from $\mathrm{OPN}^{-1-}$ and ${ }^{+/+}$mice, fixed in $4 \%$ paraformaldehyde and 3\% glutaraldehyde, transferred to Sorenson's buffer, and embedded in plastic according to standard protocols. Toluidine blue-stained $1-\mu \mathrm{m}$-thick sections were used to count the total number of myelinated axons per cross section as previously described (Mi et al., 2007). Sural nerves from $\mathrm{CLU}^{-1-}$ and ${ }^{+/+}$were processed and analyzed in the same manner.

Analysis of neuromuscular junctions. Whole mounts of extensor digitorum longus (EDL) and soleus (SOL) muscles were processed for immunostaining as described previously (Wright and Son, 2007). Briefly, muscles were postfixed in $4 \%$ paraformaldehyde for $20 \mathrm{~min}$, rinsed in PBS containing $0.1 \mathrm{~m}$ glycine, and incubated for $15 \mathrm{~min}$ with rhodamineconjugated $\alpha$-bungarotoxin (Invitrogen). The muscles were then permeabilized in $-20^{\circ} \mathrm{C}$ methanol for $5 \mathrm{~min}$ and blocked for $1 \mathrm{~h}$ in $0.2 \%$ Triton and $2 \%$ BSA in $1 \times$ PBS. Next, they were incubated overnight at $4^{\circ} \mathrm{C}$ in using the following primary antibodies diluted in the blocking solution: mouse monoclonal antibodies to neurofilaments (SMI 312; Sternberger Monoclonals) and to a synaptic vesicle protein, SV2 (Developmental Studies Hybridoma Bank) to label axons and nerve terminals, respectively; rabbit anti-cow S-100 polyclonal antibody (Dako) was used to label SCs. After incubation with the primary antibodies, muscles were rinsed in PBS and incubated with secondary antibodies in the blocking solution, for $1 \mathrm{~h}$ at room temperature with the following secondary antibodies: fluorescein-conjugated goat anti-mouse $\operatorname{IgG}_{1}$ (Jackson Immunologicals) and AlexaFluor 647-conjugated goat antirabbit (Invitrogen). After incubation with the secondary antibodies, the muscles were rinsed in PBS, mounted in Vectashield (Vector Laboratories) and stored at $-20^{\circ} \mathrm{C}$.

To evaluate reinnervation following sciatic nerve crush, each neuromuscular junction was first categorized as follows: (1) completely innervated or intact as determined by $100 \%$ overlap between the nerve terminal arbor and postsynaptic AChRs; (2) completely denervated, as identified by the lack of any nerve terminal labeling at identified postsynaptic AChRs. The presence of labeled SCs at these junctions was also used to ensure that the absence of nerve terminals was due to a lack of reinnervation, rather than a lack of antibody penetration into the muscle; or (3) partially reinnervated as determined by the presence of $<100 \%$ overlap between nerve terminals and postsynaptic AChRs. A minimum of 50 neuromuscular junctions (NMJs) were analyzed per muscle, with a minimum of five animals per group.

Electrophysiology. Electrophysiological assessment of motor conduction was performed under isofluorane anesthesia as follows. Initial baseline studies were performed before nerve injury beginning at day -7 , no significant differences were identified between $\mathrm{OPN}^{+/+}$and ${ }^{-1-}$ mice. The sciatic nerve was stimulated at the sciatic notch with recording electrodes placed at the extensor digitorum brevis muscle to capture compound motor action potential (CMAP) amplitude. All stimulating and recording electrodes were platinum subdermal needle electrodes (Grass Instruments, Astro-Med), with nerve temperature kept constant at $-37^{\circ} \mathrm{C}$ using a heating pad. Electrophysiological testing was performed on days $7,14,21$, and 28 following sciatic nerve crush.

Nerve transplants. A $10 \mathrm{~mm}$ segment of sciatic nerve was harvested from OPN and CLU ${ }^{+/+}$or ${ }^{-1-}$ mice and transplanted into host ChATeGFP mice of the same sex and age. Nerve connecter with glue was used to connect the host nerve to the proximal end of the donor nerve. The distal end of the transplanted nerve remained unattached. Whereas the distal end of the host nerve was tied off with 10-0 suture and deflected to ensure that no regenerating host sensory axons entered the donor graft. Twelve days following transplant in the CLU group, the sciatic nerve was re-exposed, the donor graft crushed $6 \mathrm{~mm}$ distal to the host-graft interface, and flurogold retrograde tracer was injected. At day 14, mice were perfused transcardially with $4 \%$ paraformaldehyde and the nerve graft was harvested beginning $6 \mathrm{~mm}$ proximal to the host-graft interface to the most distal segment of the graft. The ipsilateral and contralateral L3-L6 DRGs were also harvested in the CLU transplant group, sectioned at $7 \mu \mathrm{m}$, and the total number of flurogold-positive DRG neurons was counted in each DRG. For histological analysis of the grafted nerve, a 1 $\mathrm{mm}$ segment of nerve $4 \mathrm{~mm}$ proximal, $4 \mathrm{~mm}$ distal, and $8 \mathrm{~mm}$ distal to the host-graft interface was sectioned at $10 \mu \mathrm{m}$ on a cryostat and immunostained with antibodies to $\beta$-III tubulin and GAP-43. For the OPN transplant group the total number of ChAT-positive motor neurons per graft were counted in a minimum of three sections at each distance from the host-graft interface.

Measurement of thermal sensation. Following sciatic nerve crush, recovery of thermal sensation was tested in $\mathrm{CLU}^{-1-}$ and ${ }^{+/+}$mice using the Hargreaves apparatus. Thermal testing was performed on day -7 , $7,14,21$, and 28 relative to sciatic nerve crush. A radiant heat source was applied to plantar paws over the lateral aspect of the paw and the latency to withdrawal time was measured. Paws were inspected before and after testing to ensure that there was no thermal damage. A total of four trials for each foot were performed with $5 \mathrm{~min}$ intervals between each trail to calculate a mean value of thermal sensitivity.

Statistical analysis. Unpaired Student's $t$ tests were performed to determine significance in experimental versus control groups using StatView software (Abacus Concepts). Differences were considered statistically significant when $p<0.05$. All data are presented as means \pm SEM.

\section{Results}

\section{Gene expression differences between denervated motor and sensory pathways}

To achieve an unbiased, genome-wide view of transcriptional profiles between denervated sensory and motor pathways, we performed microarray analysis on dorsal roots (DRs) and ventral roots (VRs) that were denervated for $14 \mathrm{~d}$, with the uninjured contralateral DRs and VRs serving as controls ( $n=6$ per group). The top expression differences observed between denervated sensory and motor pathways, at a false discovery rate of $5 \%$, included 442 genes (Fig. 1a,b). Based on available literature indicating their potential therapeutic relevance (i.e., studies demonstrating roles in neurodevelopment or plasticity, secreted factors with recognized trophic properties, transcription factors with recognized neuronal and/or glial roles), 82 of 442 genes were selected for validation by real-time PCR (RT-PCR) analysis (Table 1). The majority of the selected genes showed expression levels similar to those seen in the microarray, using confirmatory RT-PCR in an independent set of experimental tissue samples (i.e., 76\% of genes that were differentially upregulated or downregulated after denervation in the microarray, showed similar expression patterns in the confirmatory RT-PCR experiments). Two of 82 selected genes, OPN (Spp1) and CLU (Clu), were chosen for further study as promising candidate factors for pathway-specific support of motor or sensory axons because of their selective upregulation and previously published research indicating their potential role to influence regeneration as secreted proteins. Changes in expression levels of both factors were further confirmed using semiquantitative RT-PCR (Fig. $1 c, d$ ). Baseline mRNA expression examined by RT-PCR in intact VRs and DRs showed that OPN was 1.7-fold higher in intact VRs than in intact DRs $(n=6$; Fig. 1c). Following denervation, OPN mRNA levels increased another 30 -fold in VR (Fig. 1d), whereas only a minimal increase in denervated DR was observed. The combination of higher baseline differences and selective upregulation after denervation in VRs indicate that OPN is a strong candidate "motor" factor associated with denervated motor pathways. The baseline mRNA expression of CLU was 1.9-fold higher in DR than in VR (Fig. 1c). Following denervation, these levels increased another 4.6-fold in DR, with minimal upregulation in denervated VR (Fig. 1d), mak- 
ing CLU a strong candidate secreted "sensory" factor associated with denervated sensory pathways.

\section{Differences in OPN and CLU expression after denervation and during reinnervation}

To better understand OPN and CLU expression patterns after peripheral nerve injury, mRNA and protein expression were examined for both factors in sciatic nerve at different time points following nerve transection and during periods of reinnervation, following nerve crush. OPN mRNA expression increased at $7 \mathrm{~d}$ following nerve transection and nerve crush (Fig. 2a). OPN mRNA expression returned toward baseline levels within 1 month of nerve crush, once the majority of reinnervation was completed (Terzis and Smith, 1987). Similarly, CLU mRNA expression increased in denervated nerves after $7 \mathrm{~d}$ (Fig. 2a). This upregulation was relatively much higher than that noted in denervated DRs, partly due to the fact that at baseline CLU mRNA levels in the sciatic nerve were extremely low. CLU mRNA levels returned to baseline levels with ensuing reinnervation at 1 month after sciatic nerve crush.

Western blot analysis of OPN protein expression in intact and sciatic nerves denervated from $1 \mathrm{~d}$ to 6 months show that OPN protein expression increased starting as early as $3 \mathrm{~d}$, with peak levels occurring $14 \mathrm{~d}$ and 1 month following denervation (Fig. $2 b$ ). OPN protein levels decreased 3 and 6 months after denervation, however protein levels were still above OPN levels in intact nerve (6 months vs 0 ). Similar to previous reports (Jander et al., 2002; Küry et al., 2005), immunolabeling of intact nerve show that OPN expression is localized in SCs surrounding peripheral axons (Fig. $2 c$, Intact). Following denervation, OPN immunoreactivity increases within denervated SCs $7 \mathrm{~d}$ following denervation (Fig. $2 c$, Denervated). Together, these results show that OPN is upregulated in acutely denervated SCs, but this upregulation is not maintained in chronically denervated SCs. This expression pattern is similar to that reported for some growth factors after denervation, including PTN and GDNF (Höke et al., 2002; Mi et al., 2007).

CLU protein expression was also detected in denervated sciatic nerve starting as early as $1 \mathrm{~d}$ and up until 6 months after denervation, with peak CLU expression observed 1 month following denervation (Fig. 2b). Using an antibody that recognizes both the secreted and intracellular forms of CLU, two bands were detected by Western blot analysis. The first band was detected at $80 \mathrm{kDa}$ and a second at $60 \mathrm{kDa}$, which correspond to the secreted and intracellular forms of CLU, respectively (Fig. $2 b$; May and Finch, 1992; Pucci et al., 2008). These results show that the intracellular form of CLU is present in denervated nerve, but at a very low level compared with the secreted form of CLU. Immunolabeling of intact nerve showed low levels of CLU expression localized within the extracellular matrix surrounding SCs and peripheral axons, as well as in subsets of SCs (Fig. $2 d$, Intact). CLU immunoreactivity increased dramatically in denervated SCs $14 \mathrm{~d}$ following nerve transection (Fig. $2 d$, Denervated). These observations show that the secreted form of CLU is robustly upregulated in acutely denervated SCs and according to the Western blot analysis, this upregulation persists, but at lower levels, with chronic denervation.

\section{OPN increases motor axon outgrowth}

The preferential upregulation of OPN in motor pathways suggested that it could serve as a motor specific neurotrophic factor. To examine this possibility, we first tested the ability of OPN to induce neurite outgrowth from cultured spinal cord explants from mice expressing YFP in sensory and motor neurons (Vyas et al., 2010). This is a culture system that has previously been used to study the neurotrophic properties of a number of growth factors on motor neurons (Vyas et al., 2010). Spinal cord explants in these cultures, once established, are able to survive for months. As previously reported, we found that, in the absence of added neurotrophic factors, motor neurons in these cultures extend axons, but these axons usually remain within the gray matter and rarely cross the gray-white matter boundary out of the explant (Fig. $3 a$, Control). In explants where OPN was applied diffusely in the culture medium, numerous axons extended out of the explant and grew extensively onto the surface of the insert (Fig. 3a, Osteopontin, arrows). Because of the multicellular nature of the spinal cord explant system, the observed effects of OPN on axon outgrowth could have been mediated through other nonneuronal cells. To examine this possibility, we also tested the ability of OPN to induce axon outgrowth on dissociated motor neuron-enriched cultures and on immortalized motor neuron cell line (Salazar-Grueso et al., 1991). In both assays, OPN induced significant outgrowth of motor neurons after only $24 \mathrm{~h}$ in culture (Fig. $3 b-d$ ). The number of neurons that extended axons, as well as the average axon length, were significantly greater in motor neurons treated with OPN compared with untreated motor neurons, providing further evidence that OPN may induce outgrowth of motor axons. 
Table 1. mRNA expression patterns for genes selected from microarray datasets

\begin{tabular}{|c|c|c|c|c|}
\hline Gene symbol & $\begin{array}{l}\text { Control } \\
\text { sensory vs } \\
\text { motor }^{a}\end{array}$ & $\begin{array}{l}\text { Denervated } \\
\text { sensory vs } \\
\text { motor }^{b}\end{array}$ & $\begin{array}{l}\text { Denervated vs } \\
\text { control } \\
\text { sensoryc }\end{array}$ & $\begin{array}{l}\text { Denervated vs } \\
\text { control } \\
\text { motor }^{d}\end{array}$ \\
\hline$A 2 m$ & -0.9 & -0.49 & 1.41 & 1 \\
\hline Adam33_predicted & -0.08 & -0.48 & 0.07 & 0.47 \\
\hline Anxa1 & -1.01 & -0.38 & 1.22 & 0.59 \\
\hline Atf3 & -0.4 & 1.27 & 3.5 & 1.84 \\
\hline Bmp7 & -0.89 & 0.13 & 2.02 & 1 \\
\hline Chrdl1 & 1.3 & -0.07 & -2.09 & -0.72 \\
\hline Clu & -1.06 & 0.84 & 0.46 & -1.43 \\
\hline Cnp1 & 0.9 & 0.42 & -0.36 & 0.11 \\
\hline Crabp2 & -1.13 & 0.46 & 1.89 & 0.3 \\
\hline Creg_predicted & 0.07 & -0.51 & 0.16 & 0.73 \\
\hline Crlf1_predicted & -0.65 & 0.53 & 1.7 & 0.51 \\
\hline Csrp2 & 0.05 & -0.79 & -0.44 & 0.39 \\
\hline Ctgf & -1.17 & 0.26 & -0.82 & -2.25 \\
\hline Cx3cl1 & -0.2 & 0.64 & 1.07 & 0.23 \\
\hline Cxcl11 & -0.72 & -0.31 & 1.91 & 1.51 \\
\hline Cxcl9 & -1.76 & -0.54 & 2.21 & 0.99 \\
\hline Ddn & 0.74 & 0.26 & -2.57 & -2.09 \\
\hline Dpysl3 & 0.05 & 0.65 & 1.53 & 0.92 \\
\hline E2f1 & -0.02 & -0.45 & 0.11 & 0.54 \\
\hline Ednrb & -0.23 & -1.29 & 0.76 & 1.82 \\
\hline Emp1 & -0.66 & 0.26 & 2.12 & 1.2 \\
\hline Fgf5 & 0.09 & 1.04 & 1.67 & 0.73 \\
\hline Gja1 & -0.74 & 0.28 & 1.85 & 0.83 \\
\hline Gli1 & -0.75 & -0.24 & -0.86 & -1.37 \\
\hline Gp38 & -0.71 & -0.07 & 1.51 & 0.87 \\
\hline Hoxd10_predicted & 0.04 & 0.91 & 0.83 & -0.05 \\
\hline Jun & -0.53 & 0.85 & 2 & 0.62 \\
\hline Lgals3bp & -0.81 & -0.66 & 1.8 & 1.66 \\
\hline Lgi4 & 0.86 & -0.18 & -1.12 & -0.08 \\
\hline LOC302378 & 0.83 & -0.09 & -0.3 & 0.63 \\
\hline LOC305472 & 0.62 & -0.07 & -0.29 & 0.4 \\
\hline LOC316539 & -0.72 & 0.99 & 1.22 & -0.48 \\
\hline LOC363517 & 0.73 & -0.59 & -1.69 & -0.37 \\
\hline LOC499194 & 1.52 & 0.13 & -4.8 & -3.41 \\
\hline Lsamp & -0.9 & 0.04 & -0.6 & -1.54 \\
\hline Mdk & -0.24 & 0.42 & 0.97 & 0.31 \\
\hline Mmp12 & 0.01 & -1.07 & 2.32 & 3.4 \\
\hline Msc_predicted & -0.24 & 0.62 & 0.88 & 0.02 \\
\hline Msln & -0.87 & 1.14 & 1.8 & -0.22 \\
\hline Nfatc4_predicted & -0.66 & 0.86 & 1.7 & 0.18 \\
\hline Nfil3 & -0.3 & 0.6 & 1.95 & 1.05 \\
\hline Nnat & -0.74 & 0.34 & 0 & -1.09 \\
\hline Nr2f1 & 0.96 & 0.51 & 0.33 & 0.79 \\
\hline 0dz3_predicted & 0.28 & 0.71 & 1.62 & 1.19 \\
\hline Pcdh17_predicted & 0.63 & -0.21 & 0.16 & 1 \\
\hline Pcdh20_predicted & -0.1 & 1.41 & 3.13 & 1.62 \\
\hline Pcp4 & 1.33 & -0.03 & -3.43 & -2.07 \\
\hline Plac8_predicted & -0.75 & 0.49 & 1.66 & 0.43 \\
\hline Plau & -0.78 & -0.73 & 1.61 & 1.57 \\
\hline Plxnd1_predicted & 0.01 & 0.58 & 0.26 & -0.3 \\
\hline Pou3f1 & 0.34 & -0.41 & -0.3 & 0.45 \\
\hline Pou3f2 & 1.22 & -0.03 & -0.18 & 1.07 \\
\hline $\operatorname{Prg}-2$ & 0.72 & 0.75 & 0.96 & 0.93 \\
\hline RGD1307599_predicted & -0.67 & 0.69 & 1.06 & -0.3 \\
\hline Ris1 & 0.09 & 1.94 & 3.5 & 1.64 \\
\hline Rxrg & 1.07 & -0.13 & -1.65 & -0.46 \\
\hline Sema4f & -0.01 & 1.02 & 1.47 & 0.43 \\
\hline Sh3gl3 & 0.36 & -1.09 & -0.43 & 1.03 \\
\hline Sostdc1 & 0.7 & -1.77 & -3.9 & 1.43 \\
\hline Sphk1 & -0.71 & -0.1 & 1.54 & 0.92 \\
\hline Spp1 & -0.46 & -1.34 & -0.55 & 0.33 \\
\hline Sulf2_predicted & -0.92 & -0.47 & 1.6 & 1.15 \\
\hline Tbx15_predicted & -1.19 & -0.25 & 0.57 & $\begin{array}{l}-\mathbf{0 . 3 7} \\
\text { Table continued }\end{array}$ \\
\hline
\end{tabular}

Table 1. Continued

\begin{tabular}{lcccc}
\hline Gene symbol & $\begin{array}{l}\text { Control } \\
\text { sensory vs } \\
\text { motor }^{a}\end{array}$ & $\begin{array}{l}\text { Denervated } \\
\text { sensory vs } \\
\text { motor }^{b}\end{array}$ & $\begin{array}{l}\text { Denervated vs } \\
\text { control } \\
\text { sensory }\end{array}$ & $\begin{array}{l}\text { Denervated vs } \\
\text { control }^{c} \\
\text { motor }^{d}\end{array}$ \\
\hline Tgfb3 & $\mathbf{- 0 . 2 2}$ & 0.41 & 1.04 & 0.41 \\
Thbd & $-\mathbf{1 . 0 7}$ & 0.11 & 0.44 & $-\mathbf{0 . 7 4}$ \\
Tieg & 0.26 & 0.51 & 1.04 & 0.79 \\
Trem2_predicted & $\mathbf{- 1 . 3 3}$ & $-\mathbf{0 . 3 8}$ & 4.1 & 3.15 \\
Trh & -0.02 & 0.96 & 6.36 & 5.38 \\
Tsnax & 0.55 & 0.43 & $-\mathbf{0 . 3}$ & -0.17 \\
Tyrobp & $\mathbf{- 0 . 7 3}$ & $-\mathbf{0 . 5 8}$ & 2.63 & 2.48 \\
Uts2 & $\mathbf{- 2 . 0 3}$ & 0.03 & -0.06 & $\mathbf{- 2 . 1 3}$ \\
Zfhx1b_predicted & $\mathbf{0 . 6 6}$ & 0.37 & 0.66 & 0.94 \\
Zic2_predicted & $\mathbf{- 1 . 3 1}$ & 1.11 & 0.88 & $\mathbf{- 1 . 5 4}$ \\
\hline
\end{tabular}

Eighty-two genes were selected from the microarray analysis; the values shown indicate log-fold difference in $\mathrm{mRNA}$ levels.

${ }^{a}$ Comparison between control, uninjured motor, and sensory pathways. Bold text indicates significantly higher levels in uninjured motor pathways, and italic text indicates significantly higher levels in uninjured sensory pathways.

${ }^{b}$ Comparison between denervated motor and sensory pathways. Bold text indicates significantly higher levels in denervated motor pathways, and italic text indicates significantly higher levels in denervated sensory pathways. 'Comparison between denervated and uninjured sensory pathways. Bold text indicates a significant decrease in denervated sensory pathways, and italic text indicates a significant increase in denervated sensory pathways.

${ }^{d}$ Comparison between denervated and uninjured motor pathways. Bold text indicates a significant decrease in denervated motor pathways, italic text indicates a significant increase in denervated motor pathways. Plain text indicates changes that were not significant.

For OPN to be considered an optimal candidate "motor" factor that selectively promotes motor neuron regeneration, it should minimally affect sensory axon outgrowth. Previous reports suggested that OPN does not induce axon outgrowth (Marsh et al., 2007) or actively inhibits axon outgrowth (Küry et al., 2005); these studies used sensory DRG neurons as their model system. To confirm these reports we examined the ability of OPN to induce axon outgrowth in primary DRG sensory neurons and found that OPN was not able to induce significant outgrowth in DRG explants (Fig. $4 a$ ) or in primary dissociated DRG neurons (Fig. 4b). Treatment of dissociated primary DRG neurons with OPN did not result in any significant difference in the number axons per neuron or affect the average length of axons. Collectively these results show that OPN can selectively induce motor, but not sensory axon outgrowth.

\section{CLU increases outgrowth of sensory neurons}

The microarray, mRNA and protein expression data show that CLU is selectively upregulated in denervated SCs of sensory nerve pathways. To test the ability of CLU to selectively induce sensory axon outgrowth, we treated cultured DRG explants and disassociated DRG sensory neurons with CLU (Fig. $4 a-c$ ). We found that CLU induced significant axon outgrowth from DRG explants (Fig. 4a) and dissociated DRG neurons (Fig. $4 b$ ). CLU-treated cultures had more axons per neuron and the axons were longer (Fig. 4c). Similar observations were not found when disassociated spinal motor neurons and $\mathrm{MN} 1$ motor neuron cells were treated with CLU (Fig. $3 d$ ), These findings strongly support a role for CLU in selective promotion of sensory axon outgrowth and potentially, in sensory nerve regeneration.

Loss of OPN impairs regeneration of sciatic nerves and limits functional outcome of nerve repair in vivo

To test the role of OPN in motor axon regeneration in vivo, we next examined the response of motor neurons to sciatic nerve crush in both young ( 2 months) and older ( 9 months) $\mathrm{OPN}^{+/+}$ and $\mathrm{OPN}^{-1-}$ mice. Morphometric analysis of distal nerve speci- 


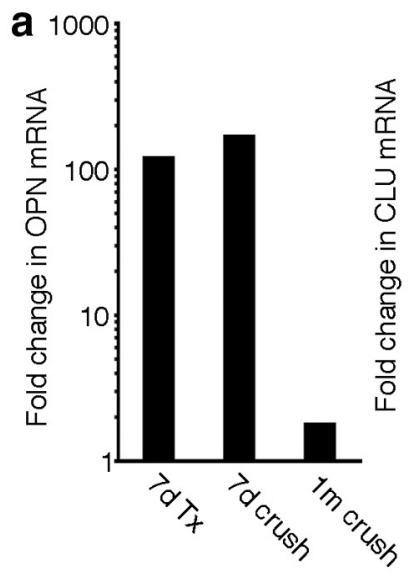

C
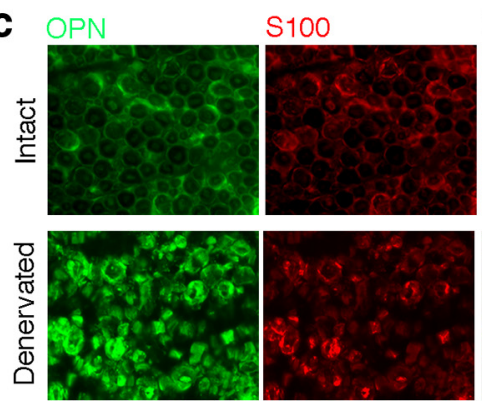
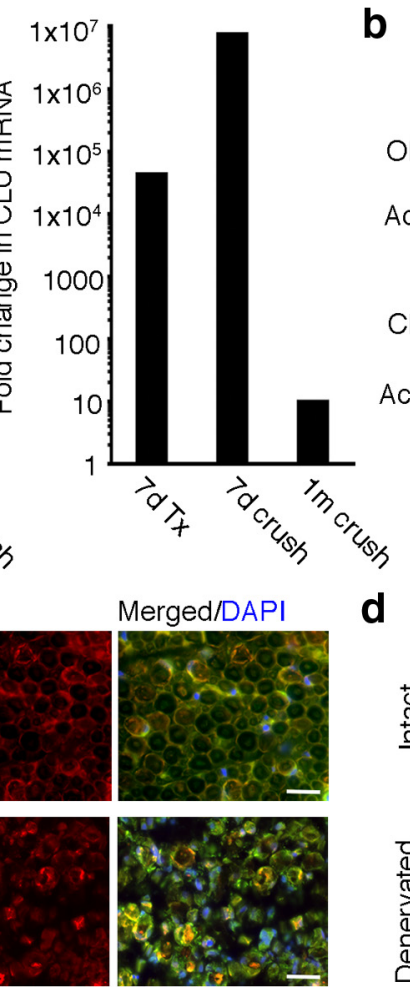

b

d
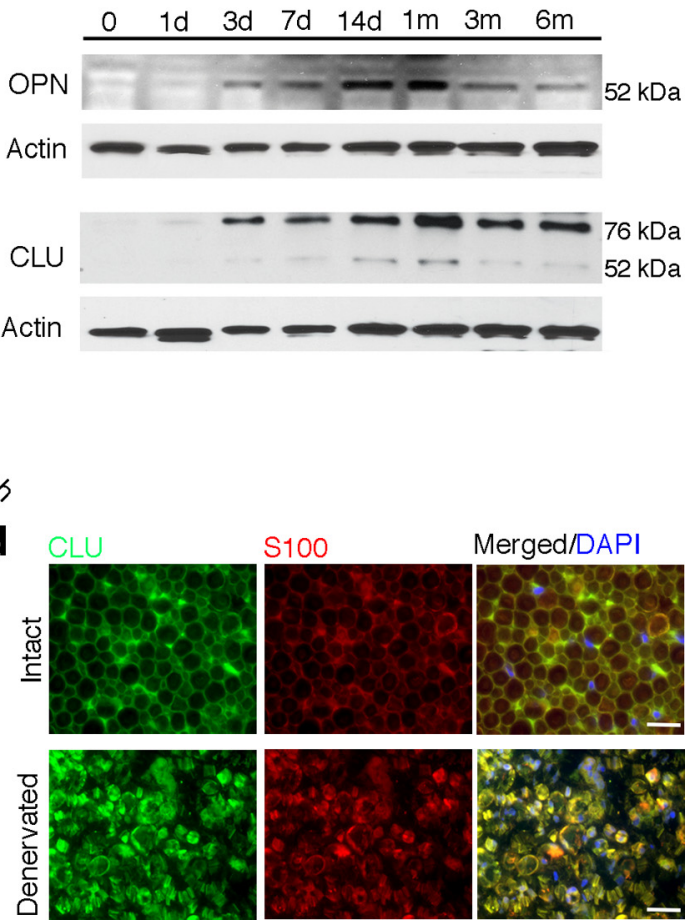

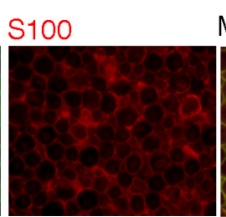

Merged/DAPI
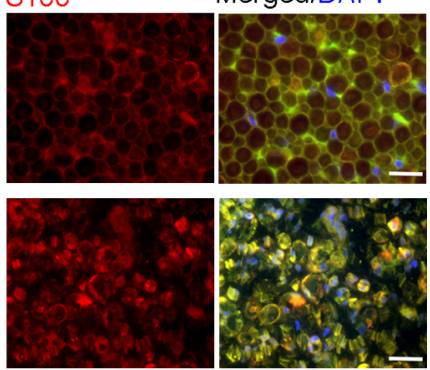

Figure 2. OPN and CLU are upregulated in denervated distal nerves cells. $\boldsymbol{a}, \mathrm{RT}-\mathrm{PCR}$ analysis shows that OPN and CLU mRNA levels are significantly upregulated in denervated sciatic nerve $7 \mathrm{~d}$ following transection ( $7 \mathrm{~d} \mathrm{Tx}$ ) and crush ( $7 \mathrm{~d}$ crush). mRNA levels for both factors return toward baseline levels 1 month following crush ( $1 \mathrm{~m}$ crush). $\boldsymbol{b}$, Western blot analysis was performed on protein isolated from distal sciatic nerve $0,1,3,7$, and $14 \mathrm{~d}$, and 1,3, and 6 months following sciatic nerve transection. OPN protein expression begins to increase at $3 \mathrm{~d}$, peaks between $14 \mathrm{~d}$ and 1 month, and decreases toward baseline levels by 3 and 6 months. The secreted form of $C L U(80 \mathrm{kDa})$, not intracellular form $(60 \mathrm{kDa})$, is the predominant isoform expressed in denervated sciatic nerve. $\mathrm{CLU}$ protein levels begin to increase at $3 \mathrm{~d}$, with peak levels occurring 1 month after denervation, expression also remains high with extended denervation after 3 and 6 months. $\boldsymbol{c}, \boldsymbol{d}$, The cellular sources of OPN and CLU are denervated Schwann cells. c, Immunolabeling for both OPN (green) and S100 (red) shows that OPN is present in SCs (c) and in some axons (c, arrows) in intact nerve. Immunoreactivity increases in SCs that were denervated for 14 d. d, Immunoreactivity for CLU (green) was detected in subsets of SCs (red) in intact nerve (arrowheads) and increased immunoreactivity was detected in SCs that were denervated for $7 \mathrm{~d}$. Scale bars, $100 \mu \mathrm{m}$.

mens 4 weeks after nerve crush shows fewer regenerating myelinated axons in older $\mathrm{OPN}^{-1-}$ mice than in OPN ${ }^{+/+}$littermates (Fig. 5a,b). The number of myelinated axons was also slightly less in young $\mathrm{OPN}^{-1-}$ mice than in $\mathrm{OPN}^{+/+}$littermates (Fig. 5b), but the difference was not statistically significant. We next examined the degree of motor reinnervation of two hindlimb muscles, the EDL and SOL muscles in young and older $\mathrm{OPN}^{+/+}$and $\mathrm{OPN}^{-1-}$ mice. NMJs in uninjured young and older, $\mathrm{OPN}^{-1-}$ mice appeared morphologically similar to NMJs observed in young and older $\mathrm{OPN}^{+/+}$mice. NMJs exhibited typical morphology with precise overlap of the presynaptic nerve terminal, terminal SCs and postsynaptic AChRs (Fig. 5d, top). Four weeks after sciatic nerve crush, however, fewer fully innervated NMJs were observed in older OPN ${ }^{-1-}$ EDL and SOL (Fig. $5 c$ ) muscles. No differences in the number of fully innervated NMJs were seen between $\mathrm{OPN}^{-1-}$ and $\mathrm{OPN}^{+/+}$EDL or SOL muscles in the young mice. The numbers of partially reinnervated and remaining denervated NMJs were significantly higher in older $\mathrm{OPN}^{-1-}$ compared with OPN ${ }^{+/+}$EDL and SOL muscles (Fig. 5c). No differences in the numbers of partially reinnervated or remaining denervated NMJs were seen between young $\mathrm{OPN}^{-1-}$ and $\mathrm{OPN}^{+/+}$EDL and SOL muscles (Fig. 5c).

CMAP amplitudes were also reduced after nerve crush in older $\mathrm{OPN}^{-1-}$ mice compared with older $\mathrm{OPN}^{+/+}$mice (Fig. 5e). CMAP amplitudes fell to unmeasurable levels after sciatic nerve crush in all groups examined, however the CMAP amplitudes of older OPN ${ }^{-1-}$ mice remained significantly lower than in
$\mathrm{OPN}^{+/+}$mice at the end point of the study (Fig. 5e). This reduction in CMAP amplitude was not observed in young $\mathrm{OPN}^{-1-}$ mice. Loss of OPN seems to affect only motor regeneration as sensory nerve regeneration was similar between $\mathrm{OPN}^{-/-}$and $\mathrm{OPN}^{+/+}$mice 4 weeks following sciatic nerve crush (Fig. 5h).

\section{Impaired motor axon regeneration through $\mathrm{OPN}^{-1-}$ peripheral nerve grafts}

Because OPN is expressed in many cells types, including motor neurons (Denhardt et al., 2001; Kazanecki et al., 2007; Wang and Denhardt, 2008), the impaired motor regeneration observed in $\mathrm{OPN}^{-1-}$ mice after sciatic nerve crush could potentially be due to loss of OPN in cell types other than SCs. To test whether it is the specific loss of OPN in SCs that impairs motor axon regeneration, a $10-12 \mathrm{~mm}$ segment of sciatic nerve was harvested from $\mathrm{OPN}^{-1-}$ and $\mathrm{OPN}{ }^{+/+}$mice (age of mice was 2 months at the time of transplant) and transplanted into mice that express eGFP under the ChAT promoter (Tallini et al., 2006). Two weeks after the transplant, the total number of ChAT-positive axons was calculated 4 and $8 \mathrm{~mm}$ distal to the host-graft interface. Significantly fewer eGFP-positive axons were present in the OPN ${ }^{-1-}$ graft 4 and $8 \mathrm{~mm}$ distal to the repair site (Fig. 5f,g). The total number of axons $4 \mathrm{~mm}$ proximal to the host-graft interface did not differ between host mice receiving $\mathrm{OPN}^{-/-}$and $\mathrm{OPN}^{+/+}$ transplants. These findings strongly suggest that the specific loss of OPN in denervated SCs impairs regeneration of motor axons in vivo. 


\section{a Control}
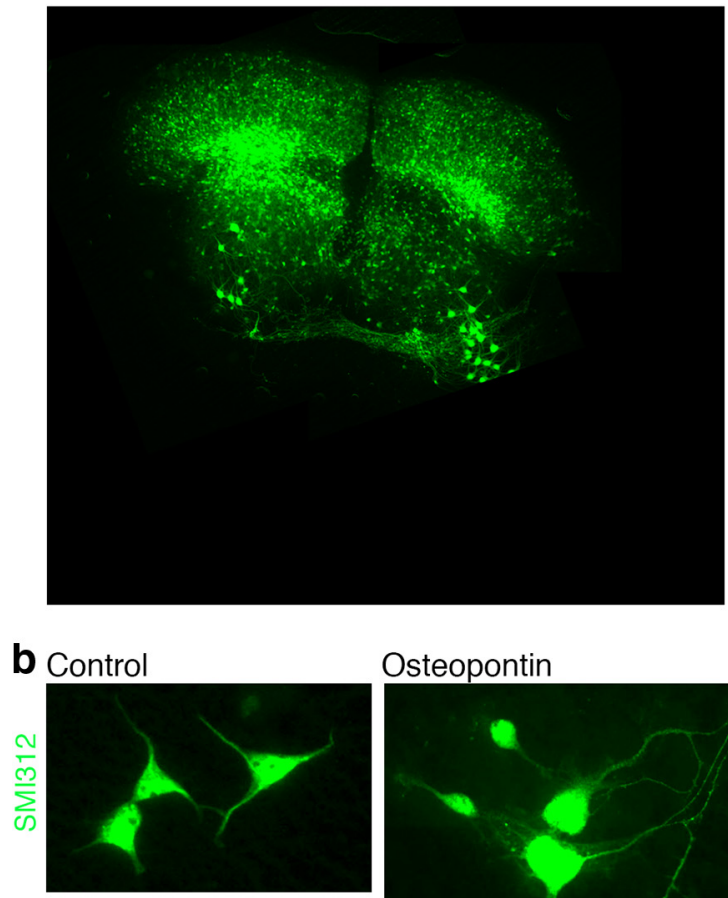

d

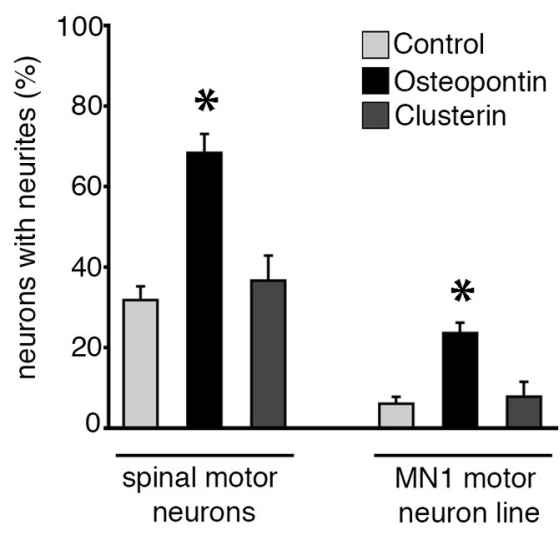

e
Osteopontin

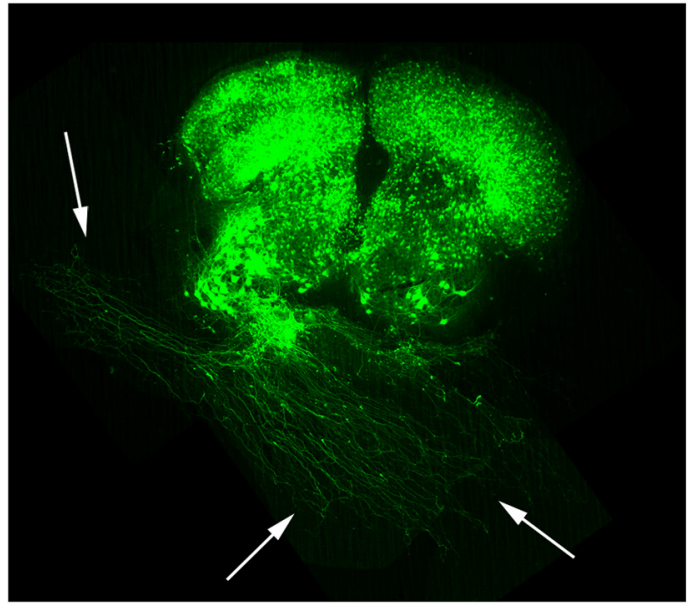

C Control
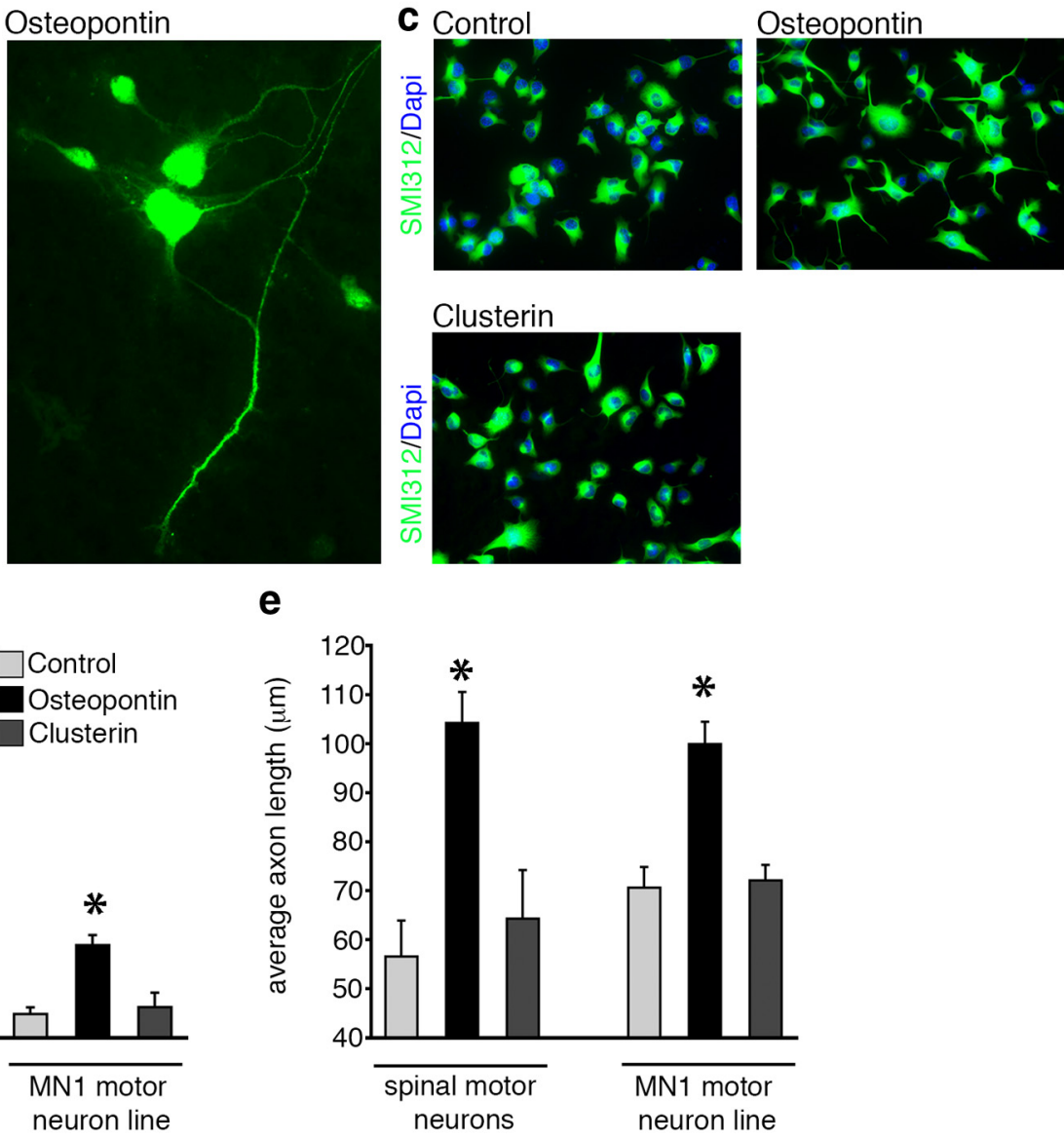

Figure 3. OPN induces motor axon outgrowth: (a, Organotypic spinal cord cultures from p4 Thy-1-YFP mouse pups were treated with recombinant OPN (1 $\mu \mathrm{g} / \mathrm{ml})$ for 1 week. OPN induced robust outgrowth of motor axons from the spinal explant compared with control treated cultures. Dissociated spinal motor neuron-enriched cultures $(\boldsymbol{b}, \boldsymbol{d}, \boldsymbol{e})$ and MN1 cell cultures ( $(\boldsymbol{c}-\boldsymbol{e})$ treated with OPN also showed increases in axon outgrowth compared with control treated cultures. This increase in motor axon outgrowth was not observed in cell cultures treated with recombinant $\mathrm{CLU}$ (1 $\mu \mathrm{g} / \mathrm{ml}$;

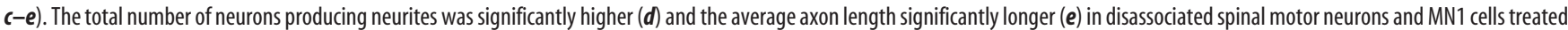
with OPN compared with control or CLU treated cells. Scale bars, $100 \mu \mathrm{m} . \boldsymbol{a}-\boldsymbol{c},{ }^{*} p \leq 0.05$ and error bars indicate SEM.

\section{Loss of CLU impairs sensory axon regeneration and functional recovery in vivo}

To evaluate the role of CLU in sensory axon regeneration in vivo, we examined the response of sensory axons to sciatic nerve crush in $\mathrm{CLU}^{+/+}$and $\mathrm{CLU}^{-/-}$mice. Morphometric analysis of the sural nerve specimens showed higher densities of regenerating myelinated axons in
$\mathrm{CLU}^{+/+}$than in $\mathrm{CLU}^{-/-}$nerves 4 weeks after crush injury (Fig. 6b,c). Loss of CLU also impaired behavioral recovery following sciatic nerve crush. Recovery of thermal sensitivity was impaired in $\mathrm{CLU}^{-/-}$mice when compared with $\mathrm{CLU}^{+/+}$mice beginning $14 \mathrm{~d}$ following crush (Fig. 6a) and continuing to the end point of the study at $28 \mathrm{~d}$. Similarly, loss of CLU also impaired cutaneous reinnervation by unmyelinated 
a Control
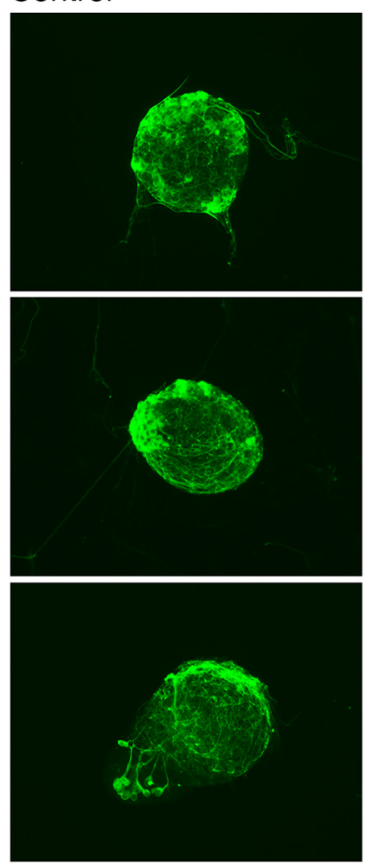

b Control

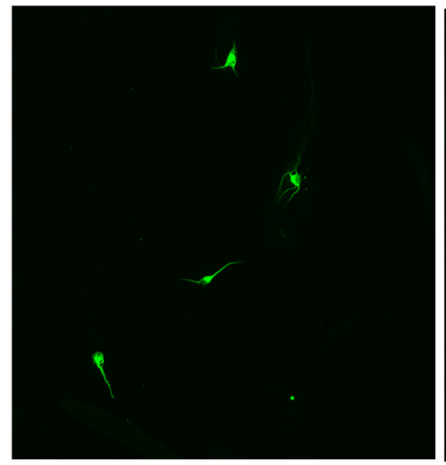

C

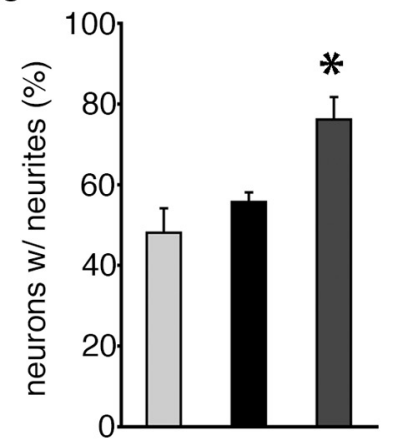

Clusterin
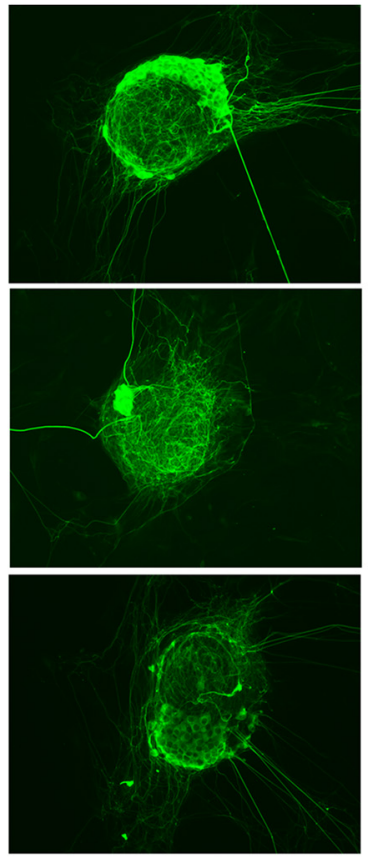

Clusterin

\section{Osteopontin}
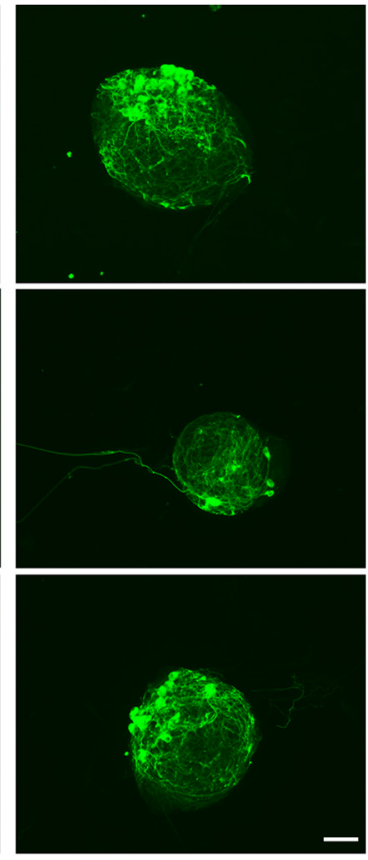

Osteopontin
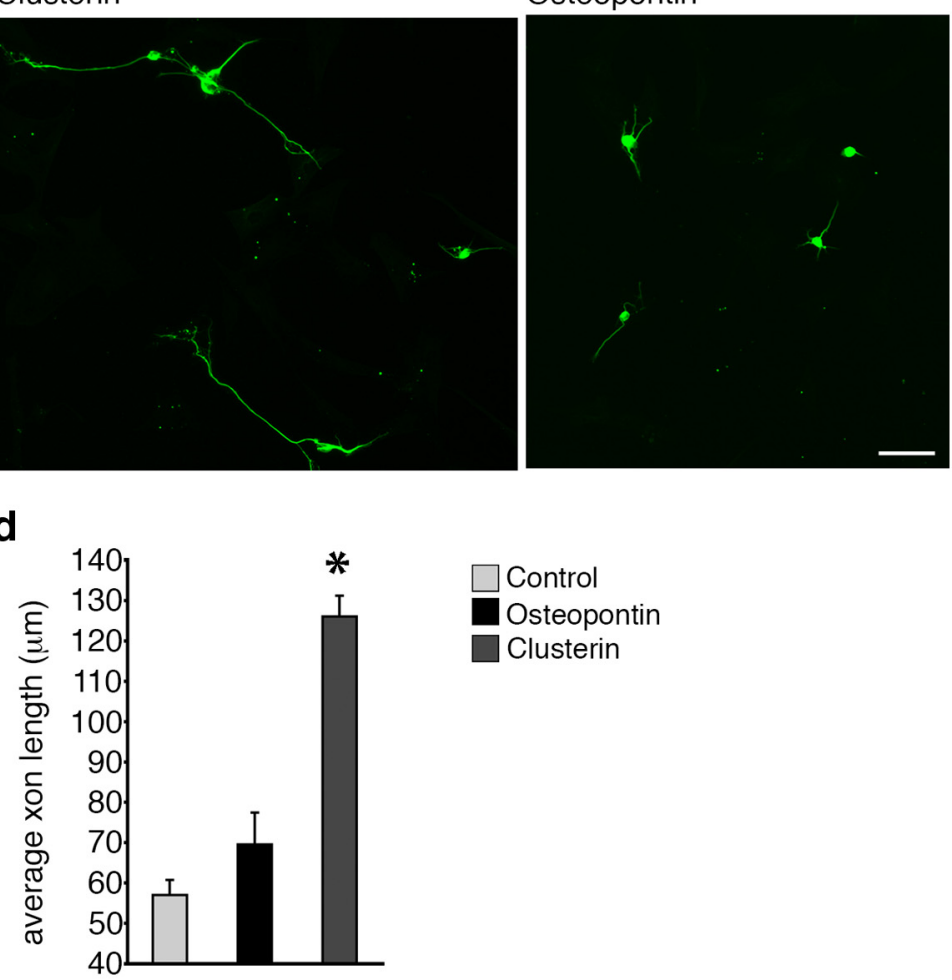

d
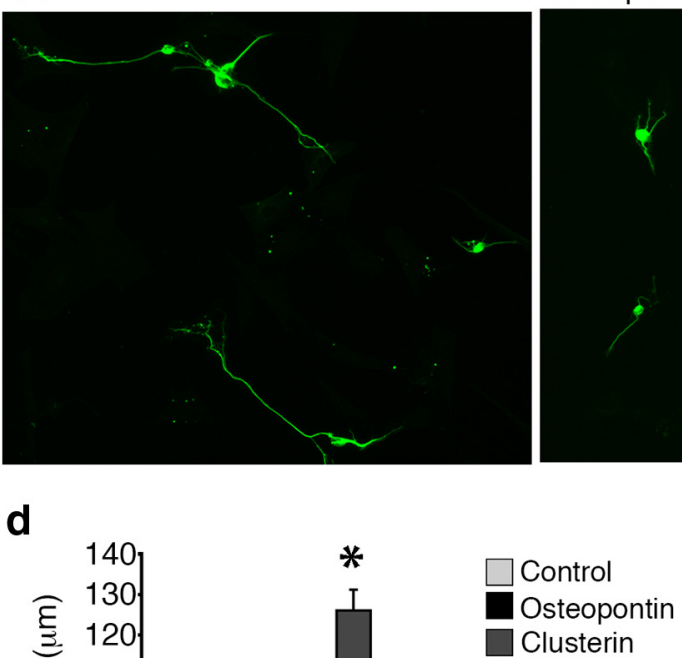

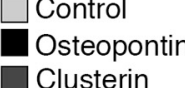

Figure 4. CLU induces sensory axon outgrowth: $\boldsymbol{a}$, Primary DRG explants treated with CLU for $24 \mathrm{~h}$ in vitro exhibited robust neurite outgrowth compared with control or OPN treated explants. $\boldsymbol{b}$, Disassociated primary DRG neurons treated with CLU also showed a significant increase in the number of neurons with neurites (c) and an increase in the average axon length per neurite (d). Scale bars: $\boldsymbol{a}, 200 \mu \mathrm{m} ; \boldsymbol{b}, 100 \mu \mathrm{m} .{ }^{*} p \leq 0.05$, error bars indicate SEM.

axons as assessed by quantifying epidermal nerve fibers 4 weeks after sciatic nerve crush in $\mathrm{CLU}^{-/-}$and CLU ${ }^{+/+}$mice (Fig. 6d,e). The total number of PGP 9.5 immunoreactive intraepidermal nerve fibers in $\mathrm{CLU}^{-1-}$ mice was significantly lower than the number observed in $\mathrm{CLU}^{+/+}$mice (Fig. 6e).

To assess whether the impairment in peripheral nerve regeneration was specifically due to a loss of CLU in SCs, we next examined regener- ation of sensory axons through $\mathrm{CLU}^{-/-}$and $\mathrm{CLU}^{+/+}$peripheral nerve grafts by flurogold retrograde labeling of ipsilateral DRGs. After 2 weeks of regeneration, significantly fewer retrogradely labeled DRG neurons were observed in host mice that received CLU ${ }^{-1-}$ transplant than host mice receiving $\mathrm{CLU}^{+/+}$transplant (Fig. $6 f$ ). Loss of CLU appears to affect only sensory nerve regeneration as motor reinnervation of hind limbs was similar in $\mathrm{CLU}^{-/-}$and $\mathrm{CLU}^{+/+}$mice (Fig. 6g). 


\section{a}

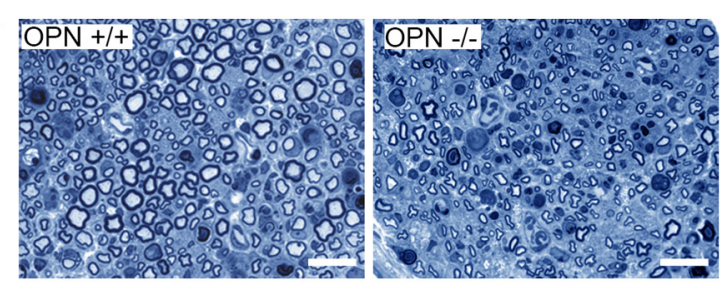

b

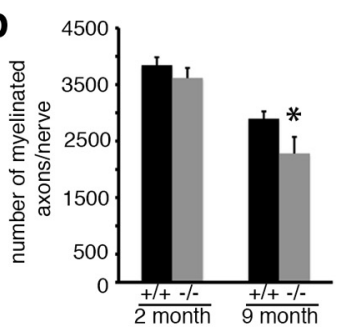

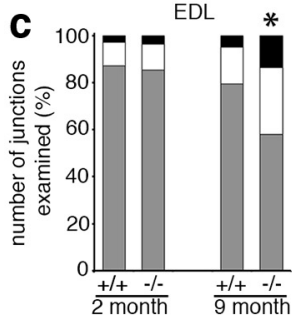

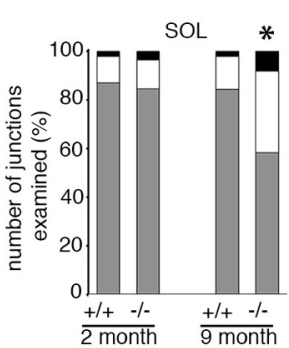

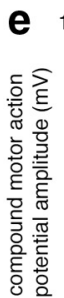

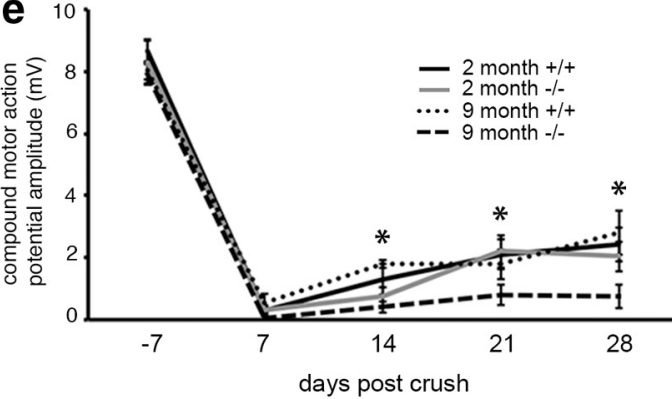

g

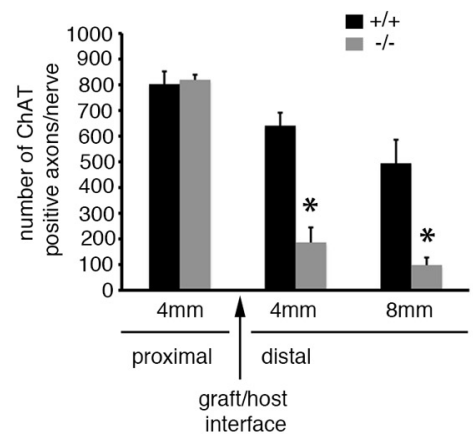

d
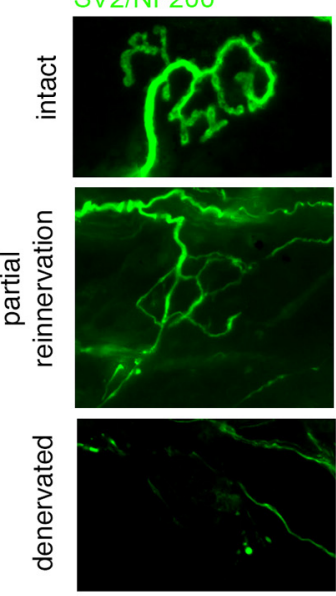

AChR

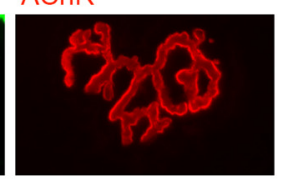

S100

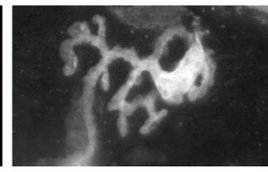

Merged
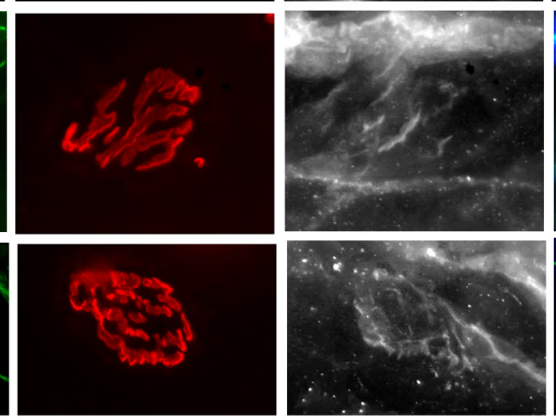

f
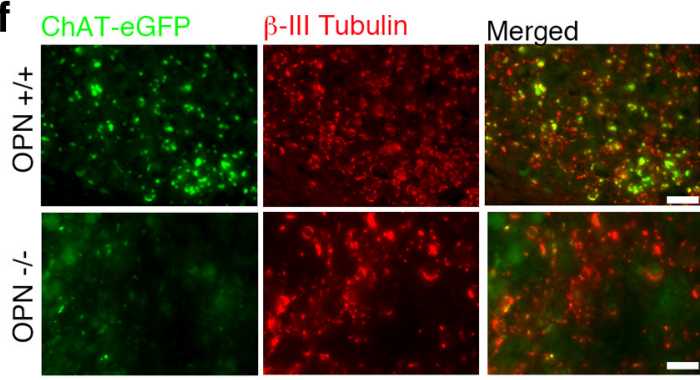

h

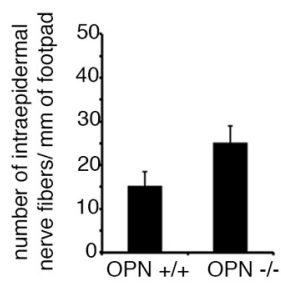

Figure 5. Absence of OPN in SCs impairs regeneration of peripheral motor axons: Peripheral nerve regeneration and motor recovery is impaired in older $0 \mathrm{PNN}^{-1-}$ mice 4 weeks after sciatic nerve crush. $\boldsymbol{a}, \boldsymbol{b}$, The total number of myelinated axon profiles in crushed and regenerated sciatic nerves of older ( 9 months), but not young ( 2 months) OPN ${ }^{-1-}$ mice was reduced in the absence of OPN. $c$, Likewise, the degree of reinnervation of neuromuscular junctions in two lower hindlimb muscles, the EDL and SOL, was impaired in older, but not young, OPN ${ }^{-1-}$ mice compared with OPN ${ }^{+/+}$mice. In c, gray bars indicate intact NMJs, white bars indicate partially reinnervated NMJs, and the balck bars indicate denervated NMJs. NMJs from uninjured OPN ${ }^{-1-}$ muscles ( $\boldsymbol{d}$, intact) appear normal, with precise alignment between nerve terminals ( $\boldsymbol{d}$, green), postsynaptic AChRs ( $\boldsymbol{d}$, red) and terminal SCs ( $\boldsymbol{d}$, gray in individual panel, blue in merged image). However, significantly fewer reinnervated (c, gray bar) NMJs were observed in the 9 month $\mathrm{OPN}^{-/-}$muscles 4 weeks after sciatic nerve crush. There was also a corresponding increase in the number of partially reinnervated NMJs $(\boldsymbol{c}$, white bar; $\boldsymbol{d}$, partial reinnervation, arrowheads indicate areas of postsynaptic AChRs unoccupied by regenerating motor axons) and denervated NMss ( $\boldsymbol{c}$, black bars; $\boldsymbol{d}$, denervated). This impaired motor axon regeneration translated into a delayed recovery of compound motor action potential amplitude in the older OPN ${ }^{-1-}$ mice as well, when compared with $\mathrm{OPN}^{+/+}$and $\mathrm{OPN}^{-1-}$ young mice and $\mathrm{OPN}^{+/+}$older mice $(\boldsymbol{e})$. The impaired regeneration of motor axons in OPN ${ }^{-1-}$ mice appears to be attributable to the absence of OPN in SCS, as motor axon regeneration through peripheral nerves grafted from $0 \mathrm{PN}^{-I-}$ mice into host mice where eGFP is expressed under the ChAT promoter, was significantly reduced compared with peripheral nerves grafted from $\mathrm{OPN}^{+/+}$mice $(\boldsymbol{f}, \boldsymbol{g})$. Two weeks after transplanting peripheral nerve grafts from $\mathrm{OPN}^{-1-}$ and ${ }^{+/+}$mice, fewer regenerating ChAT-positive motor axons were observed in OPN ${ }^{-1-}$ nerve grafts at distances of 4 and $8 \mathrm{~mm}$ distal to the host- graft interface compared with $0 \mathrm{PN}{ }^{+/+}$grafts $(\boldsymbol{f}$, ChAT-eGFP, quantified in $\boldsymbol{g})$. In contrast to the impaired motor regeneration, there was no difference in the number of regenerated sensory axons as quantified by counting intraepidermal nerve fibers in the plantar footpads 4 weeks following sciatic nerve crush $(p=0.08 ; \boldsymbol{h})$. Scale bars: $\boldsymbol{a}, 20 \mu \mathrm{m} ; \boldsymbol{d}, 20 \mu \mathrm{m} ; \boldsymbol{f}, 50 \mu \mathrm{m} .{ }^{*} p \leq 0.05$ and error bars indicate SEM. 
a

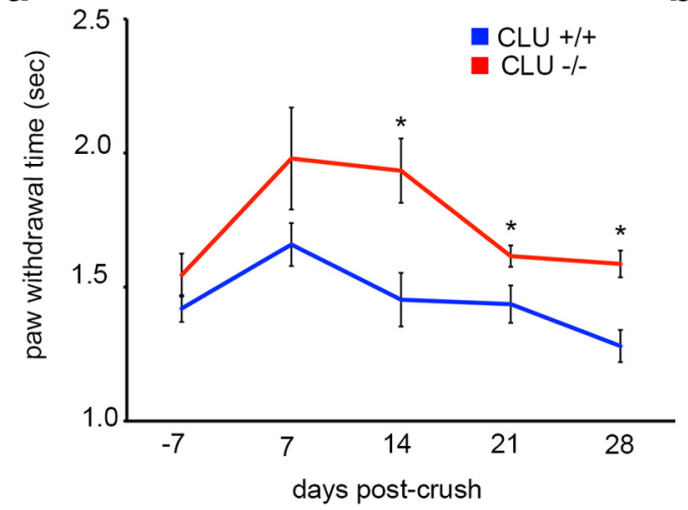

b

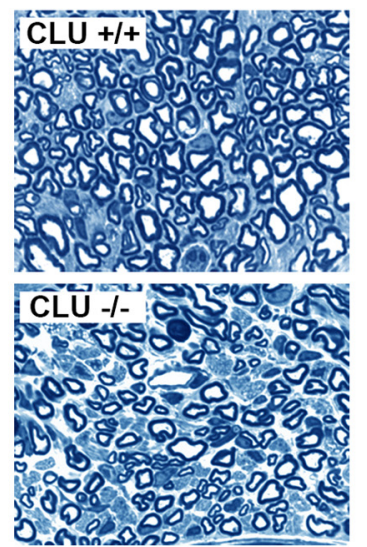

e

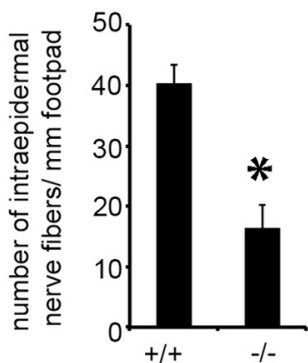

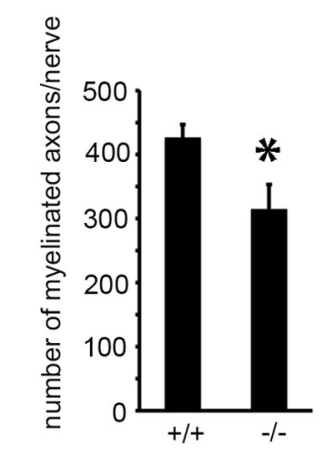

C d

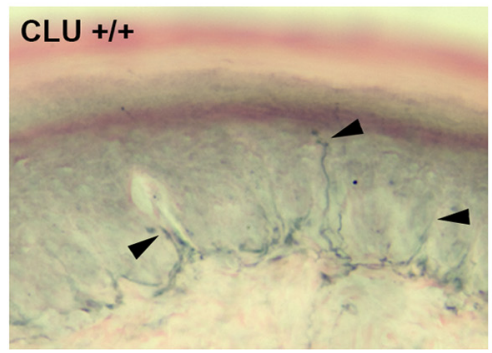

CLU -1

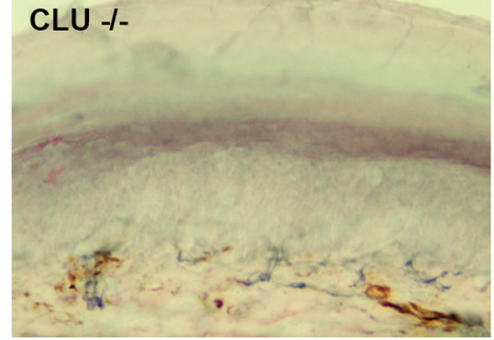

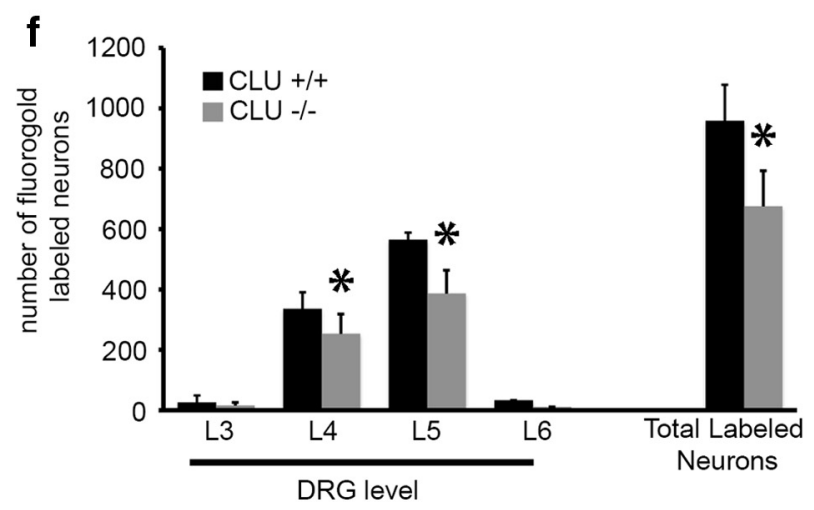

g

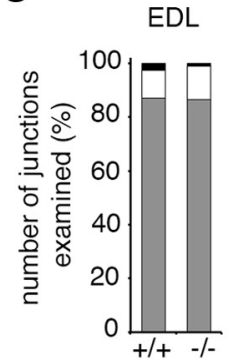

SOL

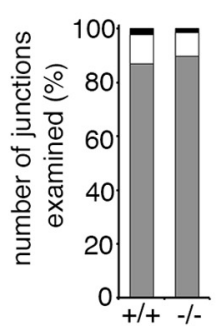

Figure 6. Absence of CLU in SCs impairs regeneration of peripheral sensory axons: Sensory axon regeneration, thermal recovery and reinnervation of peripheral sensory targets are impaired in $\mathrm{CLU}^{-/-}$mice 4 weeks after sciatic nerve crush. $\boldsymbol{a}$, The latency to withdrawal time to thermal stimuli of paws ipsilateral to the injury is increased in $\mathrm{CLU}^{-/-}$mice compared with $\mathrm{CLU}^{+/+}$mice, demonstrating reduced sensory recovery in the absence of CLU. In addition, the total number of myelinating axon profiles present in sural nerves $(\boldsymbol{b}, \boldsymbol{c})$ and the number of intraepidermal nerve fibers present in a $3 \mathrm{~mm}$ segment of footpads ipsilateral to the nerve crush $(\boldsymbol{d}, \boldsymbol{e})$ were significantly reduced in $\mathrm{CLU}^{-/-}$mice, compared with $\mathrm{CLU}^{+/+}$mice. The impaired sensory nerve regeneration in $\mathrm{CLU}^{-1-}$ mice appears to be due to the loss of $\mathrm{CLU}$ specifically within $\mathrm{SCS}$, as the regeneration of sensory axons through peripheral nerve grafts from $\mathrm{CLU}^{-1-}$ mice was impaired. There were fewer sensory neurons retrogradely labeled with fluorogold in the $\mathrm{CLU}^{-/-}$grafts compared with the number of retrogradely labeled neurons in $\mathrm{CLU}^{+/+}$grafts $(\boldsymbol{f})$. Regeneration of motor neurons in $\mathrm{CLU}^{+1+}$ and $\mathrm{CLU}^{-1-}$ was similar 4 weeks following sciatic nerve crush $(\boldsymbol{g})$. Similar numbers of intact NMJs (gray bars), partially reinnervated NMJs (white bars), and remaining denervated NMJs (black bars) in EDL and SOL hindlimb muscles ( $p \geq 0.05$ for intact, partially reinnervated and denervated NMJs). Scale bar, $20 \mu \mathrm{m} .{ }^{*} p \leq 0.05$ and error bars indicate SEM.

\section{Discussion}

Injured peripheral axons are able to mount a robust regenerative response that is largely attributed to the supportive environment provided by denervated SCs (Chen et al., 2007). Although peripheral nerves are capable of regenerating, functional outcomes are often limited due a number of factors including the inaccurate regeneration of axons toward inappropriate end organ targets (Höke et al., 2006). These misrouted axons not only fail to form functional contacts, but could also exclude appropriate regenerating axons from entering the correct pathways. A better understanding of how regenerating axons "select" their terminal pathways is needed to promote appropriate axonal pathfinding and improve functional outcomes following peripheral nerve injury.

Conditions within denervated Schwann cell endoneurial tubes are critical for appropriate axon pathfinding. Previous studies indicate a strong association between SC expression of the HNK-1 carbohydrate epitope (Martini et al., 1994; Mears et al., 2003; Eberhardt et al., 2006) and the polysialylated neural cell adhesion molecule (Franz et al., 2005) in the selective targeting of regenerating motor axons. More recent studies have also explored how differences in expression of a panel of growth factors in denervated motor and sensory pathways selectively promote regeneration of motor and sensory axons (Höke et al., 2006). Current experiments have expanded on these previous findings and results indicate a novel role for OPN and CLU in the regeneration of peripheral motor and sensory axons, respectively.

Osteopontin (also known as T-lymphocyte activation protein 1, Eta-1, or secreted phosphoprotein 1, Spp1) is a secreted glycoprotein with pleiotrophic physiological and pathological functions that influences adhesion, proliferation, differentiation, 
migration, and survival of numerous cell types (Denhardt et al., 2001; Kazanecki et al., 2007; Wang and Denhardt, 2008). Several studies indicate that OPN may be an important injury-induced, SC secreted factor that has the potential to promote motor axon regeneration. First, OPN mRNA and protein expression increase in subsets of denervated SCs following sciatic nerve injury (Jander et al., 2002; Küry et al., 2005) and in SCs of sciatic nerves with induced experimental autoimmune neuritis (Ahn et al., 2004). Second, OPN is also implicated as an important factor associated with the injured motor system as $\mathrm{OPN}^{-1-}$ mice showed impaired locomotor recovery following spinal cord injury (Hashimoto et al., 2007). Finally, OPN was found to either inhibit or have no effect on DRG sensory axon outgrowth (Jander et al., 2002; Küry et al., 2005), indicating the potential for OPN to selectively promote motor neurite outgrowth. Clusterin is an amphipathic glycoprotein found in most tissues (May and Finch, 1992; Pucci et al., 2008). CLU has been implicated in physiological and pathophysiological processes, including Alzheimer's disease, amyotrophic lateral sclerosis, and certain forms of neural injury (Pucci et al., 2008). In peripheral nerve, levels of CLU mRNA were found to increase after denervation, though the cellular source of CLU in these experiments was not clear (Bonnard et al., 1997). Another study suggests that CLU may improve recovery in a rodent model of peripheral neuropathy, though the exact mechanisms responsible for the improvements reported were uncertain (Dati et al., 2007). Other studies provide evidence that sensory neurons are not only capable of interacting with CLU, but megalin (low density lipoprotein receptor-related protein 2, LRP-2), receptor for CLU, may also be an important participant in the response of sensory neurons to injury; DRG neurons express megalin (Fleming et al., 2009) and signaling through megalin has been shown to induce neurite outgrowth in cultured central neurons and primary DRG neurons (Fitzgerald et al., 2007; Ambjørn et al., 2008; Chung et al., 2008). Additionally, sciatic nerves in megalin heterozygous $(+/-)$ mice showed impaired morphologic recovery following nerve crush (Fleming et al., 2009).

As mentioned above, a limited number of studies have shown that both OPN and CLU are expressed in rodent sciatic nerve after injury, or as a result of disease, but a definitive functional role for either of these factors in peripheral nerve regeneration has not been previously demonstrated. This is the first detailed set of experiments that show that OPN and CLU are expressed selectively in SCs of motor and sensory pathways, that they can promote outgrowth of either motor (OPN) or sensory (CLU) axons in culture, and that loss of either of these factors in SCs specifically impairs motor (OPN) or sensory (CLU) function in two rodent models of peripheral nerve injury (i.e., crush and transplant of peripheral nerve grafts).

To examine the role of these two factors in injury-induced peripheral nerve regeneration in vivo, we examined how the genetic deletion of OPN and CLU influenced the regeneration of motor and sensory axons in a mouse model of peripheral nerve injury. Absence of OPN did not result in any impairment in peripheral nerve regeneration assessed by morphometric and functional analysis in young adult mice. In older mice, however, loss of OPN lead to significantly fewer regenerating axons, reduced reinnervation of NMJs, and significant impairment in functional motor recovery. It is possible that the lack of motor impairment in the young mice was due to compensation through expression of other factors, perhaps other motor specific growth factors such as GDNF or PTN, and that this compensation was no longer sufficient as the animals aged. It is likely that other factors may be involved, which may also explain why some parameters measuring motor recovery (Fig. 5b) showed minor, though statistically significant, changes. Previous reports have shown that the regenerative response of peripheral axons becomes hindered as age progresses, ultimately resulting in impaired functional outcome (Black and Lasek, 1979; Kawabuchi et al., 2001). These observations may explain the discrepancy observed between the young and older OPN ${ }^{-1-}$ mice. Similarly, loss of CLU influenced regeneration of peripheral sensory axons, resulting in both morphometric and functional impairments in regeneration of sensory axons in $\mathrm{CLU}^{-1-}$ mice. Although functional motor and sensory deficits were observed in mice lacking OPN and CLU respectively, the impairments may not have been necessarily due to loss of these factors specifically in SCs, as both OPN and CLU are reported to be expressed in a variety of cell types in multiple tissues. The series of transplant studies using peripheral nerve grafts that were either deficient in OPN or CLU were used to test the role of SC derived OPN and CLU in selective support of regeneration. Results showing impaired motor regeneration in the $\mathrm{OPN}^{-1-}$ grafts and impaired sensory regeneration in the $\mathrm{CLU}^{-/-}$grafts strongly indicate that it is the absence of SC-derived OPN and CLU that impairs peripheral nerve regeneration.

Obviously, our findings on OPN and CLU are not the only differences between motor and sensory SCs' response to denervation. Careful evaluation and validation of other genes identified in this study will likely shed further light onto how SCs respond to modality specific denervation and support regeneration. By comparing genes that were differentially expressed between denervated ventral and dorsal roots we were able to eliminate looking at genes that were up- or downregulated as a generic response to denervation itself. As shown by our data as well as other studies, many more genes that are differentially expressed between denervated and control states of both ventral and dorsal roots. Nevertheless, comparing differentially expressed genes in the uninjured control state and comparing these genes to differentially expressed genes in the denervated state reveals an overlap of only 45 genes (Fig. $1 b$ ). The reason why there are so few genes that remained common after denervation suggests that the denervation response between sensory and motor SCs is quite distinct despite probably hundreds of genes that are differentially expressed between denervated and control samples for both sensory and motor SCs.

One limitation of our study was that it could not provide direct information on how the specific identities of SCs emerged through axon-SC interactions in a developing animal. To understand the mechanisms underlying emergence of specific identities, one will have to use a different approach and isolate both genes and proteins in a time course experiment involving developing peripheral nerves. For example, this can potentially be accomplished by isolating SCs from ventral and dorsal roots at different time points using fluorescent activated cell sorting of genetically labeled SCs. These studies are underway in our laboratory but will require extensive analysis and validation.

Overall, although these findings add significant knowledge to the growing repertoire of phenotypic differences in SCs, further analysis of the regulatory mechanisms responsible for these phenotypic differences is still needed to develop effective strategies that target regeneration of peripheral nerves in a modality specific manner. Once we fully understand the entire range of molecular interactions between regenerating axons and their associated SCs, we will be able to develop accurate and efficient therapies that promote functional recovery by enhancing the 
specificity of peripheral axon regeneration in modalityappropriate pathways.

\section{References}

Ahn M, Lee Y, Moon C, Jin JK, Matsumoto Y, Koh CS, Kim HM, Shin T (2004) Upregulation of osteopontin in Schwann cells of the sciatic nerves of Lewis rats with experimental autoimmune neuritis. Neurosci Lett 372: 137-141. CrossRef Medline

Ambjørn M, Asmussen JW, Lindstam M, Gotfryd K, Jacobsen C, Kiselyov VV, Moestrup SK, Penkowa M, Bock E, Berezin V (2008) Metallothionein and a peptide modeled after metallothionein, EmtinB, induce neuronal differentiation and survival through binding to receptors of the low-density lipoprotein receptor family. J Neurochem 104:21-37. CrossRef Medline

Black MM, Lasek RJ (1979) Slowing of the rate of axonal regeneration during growth and maturation. Exp Neurol 63:108-119. CrossRef Medline

Bonnard AS, Chan P, Fontaine M (1997) Expression of clusterin and C4 mRNA during rat peripheral nerve regeneration. Immunopharmacology 38:81-86. CrossRef Medline

Brushart TM (1988) Preferential reinnervation of motor nerves by regenerating motor axons. J Neurosci 8:1026-1031. Medline

Brushart TM (1993) Motor axons preferentially reinnervate motor pathways. J Neurosci 13:2730-2738. Medline

Brushart TM, Gerber J, Kessens P, Chen YG, Royall RM (1998) Contributions of pathway and neuron to preferential motor reinnervation. J Neurosci 18:8674-8681. Medline

Brushart TM, Aspalter M, Griffin JW, Redett R, Hameed H, Zhou C, Wright M, Vyas A, Höke A (2013) Schwann cell phenotype is regulated by axon modality and central-peripheral location, and persists in vitro. Exp Neurol 247:272-281. CrossRef Medline

Chen ZL, Yu WM, Strickland S (2007) Peripheral regeneration. Annu Rev Neurosci 30:209-233. CrossRef Medline

Chung RS, Penkowa M, Dittmann J, King CE, Bartlett C, Asmussen JW, Hidalgo J, Carrasco J, Leung YK, Walker AK, Fung SJ, Dunlop SA, Fitzgerald M, Beazley LD, Chuah MI, Vickers JC, West AK (2008) Redefining the role of metallothionein within the injured brain: extracellular metallothioneins play an important role in the astrocyte-neuron response to injury. J Biol Chem 283:15349-15358. CrossRef Medline

Coppola G (2011) Designing, performing, and interpreting a microarraybased gene expression study. Methods Mol Biol 793:417-439. CrossRef Medline

Dati G, Quattrini A, Bernasconi L, Malaguti MC, Antonsson B, Nicoletti F, Alliod C, Di Marco R, Sagot Y, Vitte PA, Hiver A, Greco B, Roach A, Zaratin PF (2007) Beneficial effects of r-h-CLU on disease severity in different animal models of peripheral neuropathies. J Neuroimmunol 190:8-17. CrossRef Medline

Denhardt DT, Noda M, O'Regan AW, Pavlin D, Berman JS (2001) Osteopontin as a means to cope with environmental insults: regulation of inflammation, tissue remodeling, and cell survival. J Clin Invest 107: 1055-1061. CrossRef Medline

Eberhardt KA, Irintchev A, Al-Majed AA, Simova O, Brushart TM, Gordon T, Schachner M (2006) BDNF/TrkB signaling regulates HNK-1 carbohydrate expression in regenerating motor nerves and promotes functional recovery after peripheral nerve repair. Exp Neurol 198:500-510. CrossRef Medline

Fitzgerald M, Nairn P, Bartlett CA, Chung RS, West AK, Beazley LD (2007) Metallothionein-IIA promotes neurite growth via the megalin receptor. Exp Brain Res 183:171-180. CrossRef Medline

Fleming CE, Mar FM, Franquinho F, Saraiva MJ, Sousa MM (2009) Transthyretin internalization by sensory neurons is megalin mediated and necessary for its neuritogenic activity. J Neurosci 29:3220-3232. CrossRef Medline

Franz CK, Rutishauser U, Rafuse VF (2005) Polysialylated neural cell adhesion molecule is necessary for selective targeting of regenerating motor neurons. J Neurosci 25:2081-2091. CrossRef Medline

Hashimoto M, Sun D, Rittling SR, Denhardt DT, Young W (2007) Osteopontin-deficient mice exhibit less inflammation, greater tissue damage, and impaired locomotor recovery from spinal cord injury compared with wild-type controls. J Neurosci 27:3603-3611. CrossRef Medline

Höke A, Gordon T, Zochodne DW, Sulaiman OA (2002) A decline in glial cell-line-derived neurotrophic factor expression is associated with im- paired regeneration after long-term Schwann cell denervation. Exp Neurol 173:77-85. CrossRef Medline

Höke A, Redett R, Hameed H, Jari R, Zhou C, Li ZB, Griffin JW, Brushart TM (2006) Schwann cells express motor and sensory phenotypes that regulate axon regeneration. J Neurosci 26:9646-9655. CrossRef Medline

Jander S, Bussini S, Neuen-Jacob E, Bosse F, Menge T, Müller HW, Stoll G (2002) Osteopontin: a novel axon-regulated Schwann cell gene. J Neurosci Res 67:156-166. CrossRef Medline

Jessen KR, Mirsky R (2002) Signals that determine Schwann cell identity. J Anat 200:367-376. CrossRef Medline

Jesuraj NJ, Nguyen PK, Wood MD, Moore AM, Borschel GH, Mackinnon SE, Sakiyama-Elbert SE (2012) Differential gene expression in motor and sensory Schwann cells in the rat femoral nerve. J Neurosci Res 90:96-104. CrossRef Medline

Kawabuchi M, Zhou CJ, Wang S, Nakamura K, Liu WT, Hirata K (2001) The spatiotemporal relationship among Schwann cells, axons and postsynaptic acetylcholine receptor regions during muscle reinnervation in aged rats. Anat Rec 264:183-202. CrossRef Medline

Kazanecki CC, Uzwiak DJ, Denhardt DT (2007) Control of osteopontin signaling and function by post-translational phosphorylation and protein folding. J Cell Biochem 102:912-924. CrossRef Medline

Küry P, Zickler P, Stoll G, Hartung HP, Jander S (2005) Osteopontin, a macrophage-derived matricellular glycoprotein, inhibits axon outgrowth. FASEB J 19:398-400. CrossRef Medline

Liaw L, Birk DE, Ballas CB, Whitsitt JS, Davidson JM, Hogan BL (1998) Altered wound healing in mice lacking a functional osteopontin gene (spp1). J Clin Invest 101:1468-1478. CrossRef Medline

Marsh BC, Kerr NC, Isles N, Denhardt DT, Wynick D (2007) Osteopontin expression and function within the dorsal root ganglion. Neuroreport 18:153-157. CrossRef Medline

Martini R, Schachner M, Brushart TM (1994) The L2/HNK-1 carbohydrate is preferentially expressed by previously motor axon-associated Schwann cells in reinnervated peripheral nerves. J Neurosci 14:7180-7191. Medline

May PC, Finch CE (1992) Sulfated glycoprotein 2: new relationships of this multifunctional protein to neurodegeneration. Trends Neurosci 15:391396. CrossRef Medline

McLaughlin L, Zhu G, Mistry M, Ley-Ebert C, Stuart WD, Florio CJ, Groen PA, Witt SA, Kimball TR, Witte DP, Harmony JA, Aronow BJ (2000) Apolipoprotein J/clusterin limits the severity of murine autoimmune myocarditis. J Clin Invest 106:1105-1113. CrossRef Medline

Mears S, Schachner M, Brushart TM (2003) Antibodies to myelinassociated glycoprotein accelerate preferential motor reinnervation. J Peripher Nerv Syst 8:91-99. CrossRef Medline

Mi R, Chen W, Höke A (2007) Pleiotrophin is a neurotrophic factor for spinal motor neurons. Proc Natl Acad Sci US A 104:4664-4669. CrossRef Medline

Pucci S, Mazzarelli P, Missiroli F, Regine F, Ricci F (2008) Neuroprotection: VEGF, IL-6, and clusterin: the dark side of the moon. Prog Brain Res 173:555-573. CrossRef Medline

Salazar-Grueso EF, Kim S, Kim H (1991) Embryonic mouse spinal cord motor neuron hybrid cells. Neuroreport 2:505-508. CrossRef Medline

Smyth GK (2004) Linear models and empirical bayes methods for assessing differential expression in microarray experiments. Stat Appl Genet Mol Biol 3:Article3. CrossRef Medline

Tallini YN, Shui B, Greene KS, Deng KY, Doran R, Fisher PJ, Zipfel W, Kotlikoff MI (2006) BAC transgenic mice express enhanced green fluorescent protein in central and peripheral cholinergic neurons. Physiol Genomics 27:391-397. CrossRef Medline

Terzis JK, Smith KJ (1987) Repair of severed peripheral nerves: comparison of the "de Medinaceli" and standard microsuture methods. Exp Neurol 96:672-680. CrossRef Medline

Vyas A, Li Z, Aspalter M, Feiner J, Höke A, Zhou C, O’Daly A, Abdullah M, Rohde C, Brushart TM (2010) An in vitro model of adult mammalian nerve repair. Exp Neurol 223:112-118. CrossRef Medline

Wang KX, Denhardt DT (2008) Osteopontin: role in immune regulation and stress responses. Cytokine Growth Factor Rev 19:333-345. CrossRef Medline

Wright MC, Son YJ (2007) Ciliary neurotrophic factor is not required for terminal sprouting and compensatory reinnervation of neuromuscular synapses: re-evaluation of CNTF null mice. Exp Neurol 205:437-448. CrossRef Medline 